\title{
Reactive Oxygen Species in Plant Interactions With Aphids
}

\section{Fiona L. Goggin* and Hillary D. Fischer}

Department of Entomology and Plant Pathology, University of Arkansas System Division of Agriculture, Fayetteville, AR, United States

Reactive oxygen species (ROS) such as hydrogen peroxide and superoxide are produced in plants in response to many biotic and abiotic stressors, and they can enhance stress adaptation in certain circumstances or mediate symptom development in others. The roles of ROS in plant-pathogen interactions have been extensively studied, but far less is known about their involvement in plant-insect interactions. A growing body of evidence, however, indicates that ROS accumulate in response to aphids, an economically damaging group of phloem-feeding insects. This review will cover the current state of knowledge about when, where, and how ROS accumulate in response to aphids, which salivary effectors modify ROS levels in plants, and how microbial associates influence ROS induction by aphids. We will also explore the potential adaptive significance of intra- and extracellular oxidative responses to aphid infestation in compatible and incompatible interactions and highlight knowledge gaps that deserve further exploration.

Keywords: aphid resistance, chloroplast, hydrogen peroxide, nitric oxide, oxidative burst, peroxisome, $\mathrm{R}$ gene, superoxide

\section{INTRODUCTION}

\section{Reactive Oxygen Species in Stress Responses}

Regulating the accumulation of reactive oxygen species (ROS) is a critical aspect of how plants adapt to environmental and biotic stresses (Foyer and Noctor, 2016). ROS such as superoxide $\left(\mathrm{O}_{2}{ }^{-}\right)$and hydrogen peroxide $\left(\mathrm{H}_{2} \mathrm{O}_{2}\right)$ are molecules that contain oxygen and that are highly reactive due to the electron receptivity of this element. They are generated as a byproduct of aerobic metabolic processes such as photosynthesis, and their accumulation is carefully limited by enzymatic and non-enzymatic antioxidants (Apel and Hirt, 2004). Stress may increase ROS levels in plants by limiting antioxidant activities and/or by causing metabolic dysfunctions that increase ROS generation (Ahmad et al., 2010). In addition, ROS can be actively generated in response to stress through genetically programmed enzymatic processes such as $\mathrm{O}_{2}{ }^{-}$production by NADPH oxidases or synthesis of photoactivating phytoalexins (Flors and Nonell, 2006). All three of these routes contribute to stress-induced ROS accumulation in plants, and this response represents a doubleedged sword (Das and Roychoudhury, 2014). On one hand, ROS can facilitate stress adaptation by activating defensive signaling networks, reprogramming gene expression, modifying cell walls, and in some cases triggering programmed cell death (i.e., the hypersensitive response) to quarantine viruses and other threats (Waszczak et al., 2018). On the other hand, if the timing and magnitude 
of ROS accumulation are not tightly controlled by the plant's antioxidant system, ROS can damage the plants' own membrane lipids, proteins, and DNA, resulting in symptom development rather than defense or acclimation (Demidchik, 2015; Czarnocka and Karpiński, 2018). For example, oxidative stress caused by prolonged, "runaway" ROS accumulation contributes to pathogenesis by necrotrophic pathogens (Barna et al., 2012), and is responsible for much of the damage caused by drought, salinity, heavy metal exposure, and other abiotic stresses (Sharma et al., 2012). In addition to the importance of the timing and magnitude of ROS accumulation, certain studies suggest that the effects of the oxidative response also depend in part upon which ROS are induced and in which cellular compartments they accumulate (Gadjev et al., 2006; Shapiguzov et al., 2012). Therefore, to understand the adaptive significance of ROS accumulation in plants under stress, it is important to know the "who, what, when, and where" of ROS accumulation. In the case of biotic stress, it is also critical to understand the mode of parasitism of the attacker and the ways in which the attacker may manipulate ROS accumulation in its host plant (Barna et al., 2012).

\section{Regulation of Reactive Oxygen Species Accumulation in the Molecular Arms Race}

The cellular redox balance represents an important battleground in the evolutionary arms race between plants and other organisms that utilize them for food and shelter. Although ROS play a role in plant interactions with a diversity of organisms including insects and parasitic plants (e.g., Liu et al., 2010; Bittner et al., 2017; Wada et al., 2019), the majority of studies to date have focused on ROS in plant-pathogen interactions. In response to many phytopathogens, plants generate rapid and transient ROS accumulation at the infection site (i.e., the oxidative burst) that helps limit infection (Lamb and Dixon, 1997). Because of its role in activating programmed cell death, the oxidative burst is especially important in controlling biotrophic or hemibiotrophic pathogens that require living host cells to complete all or part of their life cycle (Glazebrook, 2005). In addition, studies of mutants with impairments in the oxidative burst suggest that at early stages of the infection process, ROS can in some cases contribute to plant defenses against pathogens that live on dead and dying cells (i.e., necrotrophs) (Lehmann et al., 2015). Loss of function of NADPH oxidases in different host plant species has been reported to increase susceptibility to the necrotrophic fungi Alternaria brassicicola, Rhizoctonia solani, and Botrytis cinerea (Pogány et al., 2009; Foley et al., 2013; Li et al., 2015).

Because of the importance of the oxidative burst in plant defense, many pathogens produce effectors that inhibit ROS accumulation in the host plant (Jwa and Hwang, 2017). For example, the powdery mildew Blumeria graminis f. sp. hordei secretes a catalase to scavenge $\mathrm{H}_{2} \mathrm{O}_{2}$ at the infection site (Zhang et al., 2004), and Ustilago maydis, the causal agent of corn smut, decreases ROS production in the host by secreting an inhibitor of peroxidases (Hemetsberger et al., 2012). In contrast to these examples, however, necrotrophic pathogens actively promote ROS accumulation at the infection site during certain phases of the infection process. Fusicoccum amygdali for example inhibits catalase activity in host cells (Beffagna and Lutzu, 2007), and $B$. cinerea utilizes its own NADPH oxidases to generate ROS and facilitate infection (Segmüller et al., 2008). The explanation for this apparent contradiction lies in the timing and localization of ROS accumulation; rapid, transient accumulation of ROS at the initial site of infection can inhibit both biotrophs and necrotrophs, whereas slower, more diffuse and sustained ROS accumulation can facilitate necrotrophic infection and symptom development (Pogány et al., 2009; Lehmann et al., 2015).

In addition, ROS may have different consequences depending upon their location within or outside the cell. The oxidative burst associated with pathogen resistance typically involves ROS accumulation in the apoplast, but pathogens and other stresses can also induce ROS generation within cellular compartments such as the chloroplasts and peroxisomes (Kuźniak and Kopczewski, 2020). The same ROS can have different impacts within different organelles; for example, transcript profiles in Arabidopsis thaliana lines with altered ROS accumulation suggest that $\mathrm{H}_{2} \mathrm{O}_{2}$ in the chloroplast activates defensive phytoalexin synthesis whereas $\mathrm{H}_{2} \mathrm{O}_{2}$ in the peroxisome activates protein repair and stress acclimation (Sewelam et al., 2014). While intracellular ROS can in some cases have a protective role, in others it can cause oxidative damage and facilitate infection. For example, in the case of $B$. cinerea, persistent ROS levels in the chloroplast potentiate disease development (Rossi et al., 2017), even though early, NADPH-dependent ROS accumulation in the apoplast inhibits infection (Li et al., 2015).

Thus, whether ROS accumulation is adaptive to the plant or to the pathogen depends in part on the pathogen's lifestyle and its ability to manipulate the host's oxidative response, as well as the timing and location of ROS accumulation. This conceptual framework is useful to explore the influence of ROS in plant interactions with other biotic stressors.

\section{Aphids as Plant Parasites}

Aphids (Hemiptera:Aphididae) are a large family of sap-feeding herbivorous insects that have many commonalities with plant pathogens (Kaloshian and Walling, 2005). They have coevolved with plants for millions of years (Peccoud et al., 2010), and typically spend their entire lives on their host plants, relying on them for food and shelter. Like plant pathogens, the more than 4,500 extant species of aphids that feed on trees, shrubs, and herbaceous plants display a diversity of lifestyles and modes of plant parasitism (Blackman and Eastop, 2000, 2006). Although most species utilize their slender, piecing-sucking stylets to ingest sap from the phloem sieve elements with occasional bouts of ingestion from the xylem (Tjallingii and Esch, 1993), some species, especially those that feed on woody trunks or stems, feed primarily from parenchyma cells (Pointeau et al., 2012). In addition, while many aphids traverse a primarily intercellular route to reach their feeding sites, sampling cells along the way without causing extensive cellular disruption, certain aphids such as the Russian wheat aphid (Diuraphis noxia) also perform frequent, damaging intracellular probes (Pollard, 1973; Tjallingii and Esch, 1993; Saheed et al., 2007). 
In part because of this variation in feeding behavior, different aphid species differ in their impacts on host plants. Some species extract nutrients without causing obvious symptoms, others manipulate plant growth and development to induce galls that can support multiple generations of aphids, and yet others such as the Russian wheat aphid or the greenbug (Schizaphis graminum) have a more "burnt-earth" approach, causing extensive necrosis and even death of the plant within a relatively short time frame (Miles, 1989; Goggin et al., 2017). Thus, although all aphids are "biotrophs" in the sense that they feed on living tissues, some can, like necrotrophic pathogens, cause extensive necrosis and have relatively short-term residencies on their host plants.

The diversity of symptoms induced by aphids is also related to the diversity of salivary secretions they produce. The composition of aphid saliva varies among different species and different populations and may be influenced by the symbionts they carry (Rao et al., 2013; Chaudhary et al., 2014; Wang et al., 2020). Similar to pathogen effectors, the salivary proteins that aphids secrete during penetration and feeding can facilitate the infestation process on one hand or trigger plant defenses on the other (Bos et al., 2010; Atamian et al., 2013; Elzinga et al., 2014). Moreover, aphid salivary secretions can also contain phytopathogenic viruses because aphids are common virus vectors (Stevens and Lacomme, 2017).

Perhaps because of the similarities between aphids and pathogens and also because of their close associations with bacterial symbionts and viruses, there is considerable overlap between plant responses to pathogens and plant responses to aphids (Kaloshian and Walling, 2005). In particular, many aphid species induce ROS accumulation in their host plants (Tables 1, 2). In addition, plants utilize the same family of nucleotide-binding, leucine-rich repeat resistance genes ( $R$ genes) to block parasitism by certain aphids as to combat pathogens such as bacteria, fungi, and viruses (Rossi et al., 1998; Boissot et al., 2016); furthermore, just as virulent pathogen strains have evolved to overcome $\mathrm{R}$ genes for disease resistance, virulent aphid isolates have emerged to attack resistant cultivars (Goggin et al., 2001; Sun et al., 2020). These putative genefor-gene interactions provide useful study systems in which to explore the roles of ROS in plant-aphid interactions. ROS accumulation can be compared in incompatible interactions (i.e., avirulent aphids on resistant host genotypes) versus compatible interactions (avirulent aphids on susceptible plant genotypes, or virulent aphids on either genotype) to identify correlations between ROS and resistance or susceptibility (several examples included in Table 2).

In summary, plant-aphid interactions display many parallels with plant-pathogen interactions which provide a framework to explore the potential roles of ROS in plant responses to aphid infestation.

\section{Objectives}

Although aphids can induce ROS accumulation in their host plants (Tables 1, 2), the contributions of ROS to plant defense or to symptom development in plant-aphid interactions are not yet well-understood. To begin to address this knowledge gap, this review will synthesize what we know about aphid-responsive ROS accumulation with an emphasis on the " 5 Ws": who, what, when, where, and why. We will consider the factors in aphids that influence ROS accumulation in the host (i.e., "who"), the different RO species that accumulate in infested plants ("what"), and the spatial and temporal dynamics of ROS responses ("when and where") in compatible and incompatible interactions to explore the adaptive significance ("why") of oxidative responses to aphid infestation.

\section{FACTORS IN APHIDS THAT MODIFY HOST REACTIVE OXYGEN SPECIES}

There are several possible mechanisms through which aphids may alter ROS levels in plants. The earliest studies of oxidative responses to aphids proposed that they are the result of oxidases in aphid saliva that facilitate the infestation process by detoxifying plant defenses and modifying plant growth (Miles, 1978, 1999). This hypothesis is supported by observations that aphid saliva contains peroxidases and other oxidizing enzymes (Miles, 1999; Carolan et al., 2009, 2011; Nicholson and Puterka, 2014), and that watery saliva collected from the pea aphid (Acyrthosiphon pisum) and the spotted alfalfa aphid (Therioaphis trifolii maculata) can generate $\mathrm{H}_{2} \mathrm{O}_{2}$ in vitro when provided with catechin as a substrate (Madhusudhan and Miles, 1998). More recently, however, a larger number of studies have pursued the hypothesis that ROS are actively generated by the plant in response to aphids as a result of non-self recognition and immune signaling (reviewed in Hogenhout and Bos, 2011). Early evidence for this hypothesis included studies in Arabidopsis that showed that loss of function of plant NADPH oxidases influence aphid population growth (Miller et al., 2009; Jaouannet et al., 2015) and that impaired immune signaling in the plant inhibit ROS production in response to aphid extracts (Prince et al., 2014).

By analogy with plant-pathogen interactions, the recognition process leading to aphid-responsive ROS generation in plants could involve detection of (1) damage-associated molecular patterns (DAMPs) that result from cleavage of plant molecules by the invader; (2) widely-conserved molecular patterns that occur in invading organisms but not in plants; or (3) specific effector proteins found in some but not all species and isolates of invader [reviewed in Jwa and Hwang (2017) and Hou et al. (2019)]. Recently, cathepsin B3 has been identified as an effector protein that varies among Myzus persicae lineages and that induces $\mathrm{H}_{2} \mathrm{O}_{2}$ accumulation by physically interacting with a kinase in tobacco that activates NADPH oxidase-dependent ROS generation (Guo et al., 2020). In addition to recognizing aphid effector proteins such as cathepsin B3, plants may also respond to molecular signatures synthesized by aphids' microbial associates. The GroEL protein present in aphid saliva is synthesized by the obligate endosymbiont 
TABLE 1 | Evidence that aphids induce reactive oxygen species (ROS) accumulation in compatible interactions.

\begin{tabular}{|c|c|c|}
\hline Aphid species & Plant species & Redox response to aphids \\
\hline $\begin{array}{l}\text { Acyrthosiphon pisum } \\
\text { (Łukaszewicz et al., 2021) }\end{array}$ & $\begin{array}{l}\text { Pisum sativum } \\
\text { Fabaceae }\end{array}$ & $\begin{array}{l}\text { Increased } \mathrm{H}_{2} \mathrm{O}_{2} \text { and } \mathrm{O}_{2}-\text { but did not impact } \mathrm{OH} \text {. Both } \\
\text { superoxide dismutase (SOD) and ascorbate peroxidase } \\
\text { (APX) activity increased at later timepoints than ROS } \\
\text { accumulation. }\end{array}$ \\
\hline A. pisum (Woźniak et al., 2019) & P. sativum & $\begin{array}{l}\text { Increased } \mathrm{H}_{2} \mathrm{O}_{2} \text { in the epidermal cells of leaves, with } \\
\text { strong accumulation in cell walls. No strong or } \\
\text { consistent changes in } \mathrm{O}_{2}^{-} \text {. Transiently suppressed } \\
\text { SOD activity in roots and leaves; increased } \\
\text { semiquinone radicals and peroxidase (POX) activity in } \\
\text { foliage; and an increase in a marker of lipid peroxidation } \\
\text { in roots and leaves. }\end{array}$ \\
\hline A. pisum (Łukasik et al., 2017) & $\begin{array}{l}\text { P. sativum, Vicia } \\
\text { faba, and Vicia } \\
\text { sativa } \\
\text { Fabaceae }\end{array}$ & $\begin{array}{l}\text { In all three hosts, transient } \mathrm{H}_{2} \mathrm{O}_{2} \text { accumulation and } \\
\text { initially suppressed catalase (CAT) activity, with a } \\
\text { subsequent increase at later time points. APX activity } \\
\text { varied among time points and among species. }\end{array}$ \\
\hline A. pisum (Mai et al., 2013) & P. sativum & $\begin{array}{l}\text { Increased } \mathrm{H}_{2} \mathrm{O}_{2}, \mathrm{O}_{2}^{-} \text {, semiquinone radicals, } \mathrm{SOD} \text { and } \\
\text { CAT activity, and a marker of lipid peroxidation. }\end{array}$ \\
\hline
\end{tabular}

Aphis craccivora ${ }^{1}$ (Mai et al., $\quad$ Glycine max 2017)

Fabaceae

A. craccivora ${ }^{1}$ (Mai et al., 2016) G. $\max$

Brachycorynella asparagi*2

(Borowiak-Sobkowiak et al., 2016)

\section{Cinara tujafilina ${ }^{3}$ (Durak et al., 2019)}

Myzus persicae extract (Prince et al., 2014)

M. persicae (Ren et al., 2014)

M. persicae (Kerchev et al., 2012)

Pemphigus bursarius ${ }^{4}$ and Pemphigus phenax ${ }^{4}$ (Kmieć and Kot, 2021)

Pemphigus spyrothecae ${ }^{5}$ (Kot and Kmieć, 2020)

P. nigra

Thuja orientalis Cupressaceae

Arabidopsis thaliana Brassicaceae

Nicotiana tabacum Solanaceae

Solanum tuberosum Solanaceae Populus nigra Salicaceae Schizaphis graminum ${ }^{6}$ and Sitobion avenae, (Zhang et al., 2019) Poaceae
Triticum aestivum Increased $\mathrm{H}_{2} \mathrm{O}_{2}$ in response to both aphid species, but

Increased $\mathrm{O}_{2}{ }^{-}$and $\mathrm{H}_{2} \mathrm{O}_{2}$, SOD, CAT, and glutathione peroxidase (GPX) activity, and a marker of lipid peroxidation. ROS, antioxidant activities, and symptom development all increased with increasing infestation levels.

Increased $\mathrm{H}_{2} \mathrm{O}_{2}$ and $\mathrm{POX}$ activity, with higher infestation levels inducing stronger responses.

Induced $\mathrm{H}_{2} \mathrm{O}_{2}, \mathrm{O}_{2}{ }^{-}$, and semiquinone radicals in 1and 2-month old plants, as well as reduced SOD activity in 1-month old plants. Oxidative responses were stronger and more rapid in younger plants, and in response to higher aphid infestation levels. In samples with low ROS induction, $\mathrm{H}_{2} \mathrm{O}_{2}$ was found in the cell walls, whereas in samples with the highest $\mathrm{ROS}, \mathrm{H}_{2} \mathrm{O}_{2}$, and $\mathrm{O}_{2}{ }^{-}$appeared to be primarily localized to the cytoplasm.

Increased $\mathrm{O}_{2}{ }^{-}$, SOD, and semiquinone radicals. The early phases of the response were stronger in response to higher aphid densities.

Increased $\mathrm{ROS}\left(\mathrm{H}_{2} \mathrm{O}_{2}\right.$ or $\mathrm{O}_{2}{ }^{-}$, measured with a luminol assay) was observed in response to an extract consisting of ground aphids in wild-type plants, but not in a mutant with impaired NADPH oxidase activity. Efflux of $\mathrm{H}_{2} \mathrm{O}_{2}$ from cells, and increased POD and CAT activities.

Increased $\mathrm{H}_{2} \mathrm{O}_{2}$, polyphenols, and POX activity; decreased expression of a peroxisomal CAT and a chloroplastic SOD.

In response to $P$. phenax, $\mathrm{H}_{2} \mathrm{O}_{2}$ was decreased in the tissue surrounding the gall, but not within the gall itself. $P$. bursarius did not impact $\mathrm{H}_{2} \mathrm{O}_{2}$. Fluctuations in guaiacol peroxidase (GPOD) and APX activity as well as a marker of lipid peroxidation were observed in galled tissue and adjacent leaf tissue in response to both aphids.

$\mathrm{H}_{2} \mathrm{O}_{2}$ was increased in the gall tissue but decreased in the surrounding leaf tissue compared with intact, non-galled leaves. Decreased GPOD and APX activity as well as a decrease in a marker of lipid peroxidation were also observed.

\section{Timing of ROS response}

Observations at 24, 48, and $72 \mathrm{~h}$ after infestation of pea seedlings. While $\mathrm{H}_{2} \mathrm{O}_{2}$ peaked at $24 \mathrm{~h}$ and remained higher than controls at $48 \mathrm{~h}, \mathrm{O}_{2}{ }^{-}$only peaked at $48 \mathrm{~h}$.

Observations at 24,48 , and $72 \mathrm{~h}$, in roots as well as leaves. In response to aphids, $\mathrm{H}_{2} \mathrm{O}_{2}$ in leaves was higher than controls at $24 \mathrm{~h}$, was lower than controls at $48 \mathrm{~h}$, and returned to normal at $72 \mathrm{~h}$.

Observations at 1, 2, 4, 6, 24, 48, and $72 \mathrm{~h} . \mathrm{H}_{2} \mathrm{O}_{2}$ increased incrementally from 1 to $6 \mathrm{~h}$, and then decreased incrementally from 6 to $48 \mathrm{~h}$.

Observations at 24, 48, 72, and 96 h after infestation. $\mathrm{H}_{2} \mathrm{O}_{2}$ was significantly elevated only at $24 \mathrm{~h}$, whereas $\mathrm{O}_{2}-$ steadily increased from 24 to $96 \mathrm{~h}$.

Observations at 6, 12, 24, 48, 72, and 96 h. $\mathrm{O}_{2}^{-}$ and $\mathrm{H}_{2} \mathrm{O}_{2}$ were elevated at all time points from 6 to $96 \mathrm{~h}$, with $\mathrm{O}_{2}-$ peaking earlier $(\sim 12 \mathrm{~h})$ than $\mathrm{H}_{2} \mathrm{O}_{2}$ ( 24 h). Higher aphid infestations caused earlier ROS induction than lower infestation levels.

Observations at 6, 12, 24, 48, 72, and 96 h. $\mathrm{H}_{2} \mathrm{O}_{2}$ was elevated at 6-24 h, with a maximum at $12 \mathrm{~h}$.

Observations at 24, 48, 72, and 96 h. $\mathrm{H}_{2} \mathrm{O}_{2}$ and $\mathrm{O}_{2}{ }^{-}$increased incrementally from 24 to $96 \mathrm{~h}$.

Observations at 24, 48, 72, and $96 \mathrm{~h}$, and at 2 and 4 weeks. The highest $\mathrm{O}_{2}{ }^{-}$was observed at $24 \mathrm{~h}$, but the response persisted up to 2 weeks post-infestation.

Observations at 0-600 min after treatment with aphid extract. A first ROS peak seen at $\sim 5-25 \mathrm{~min}$, and a second peak at $\sim 90-540 \mathrm{~min}$.

Observations at $2 \mathrm{~h}, 15 \mathrm{~h}$, and 5 days. $\mathrm{H}_{2} \mathrm{O}_{2}$ efflux seen at all time points, with the highest efflux at $15 \mathrm{~h}$.

Observations at 8,24 , and $48 \mathrm{~h}$ after infestation. $\mathrm{H}_{2} \mathrm{O}_{2}$ increased at $48 \mathrm{~h}$.

Observed once when galls were at maturity (approx. 1 month after initial gall formation).

Observed once when galls reached full maturity (approx. 1 month after initial gall formation), at the time of full gall development.

Observations at 12, 24, 48, and $72 \mathrm{~h}$ after infestation. S. graminum induced $\mathrm{H}_{2} \mathrm{O}_{2}$ at all time points, w/highest levels at $48 \mathrm{~h}$. The response to S. avenae was significantly different from controls only at $48 \mathrm{~h}$. 
TABLE 1 | (Continued)

\begin{tabular}{|c|c|c|c|}
\hline Aphid species & Plant species & Redox response to aphids & Timing of ROS response \\
\hline $\begin{array}{l}\text { S. graminum and } \\
\text { Rhopalosiphum padi } \\
\text { (Argandoña et al., 2001) }\end{array}$ & $\begin{array}{l}\text { Hordeum vulgare } \\
\text { Poaceae }\end{array}$ & Increased $\mathrm{H}_{2} \mathrm{O}_{2}$ and peroxidase activity. & $\begin{array}{l}\text { Observations at } 0-35 \text { min. A transient increase in } \mathrm{H}_{2} \mathrm{O}_{2} \\
\text { seen at } 20 \mathrm{~min} \text {, returning to baseline by } 30 \text { min. }\end{array}$ \\
\hline $\begin{array}{l}\text { Tetraneura ulmi }{ }^{7} \text { (Kmieć } \\
\text { et al., 2018) }\end{array}$ & $\begin{array}{l}\text { Ulmus pumila } \\
\text { Ulmaceae }\end{array}$ & $\begin{array}{l}\mathrm{H}_{2} \mathrm{O}_{2} \text { accumulated in the gall and in adjacent leaf tissue } \\
\text { with and without evident signs of damage. Decreased } \\
\text { CAT, APX, and GPOD activity and increased lipid } \\
\text { peroxidation were also observed in galls late in } \\
\text { development. CAT, APX, and GPOD also fluctuated in } \\
\text { adjacent tissues over the course of gall development. }\end{array}$ & $\begin{array}{l}\text { Observations at } 3 \text { time points: early, mid- and late gall } \\
\text { development. The highest } \mathrm{H}_{2} \mathrm{O}_{2} \text { levels were observed } \\
\text { in adjacent undamaged tissue in mid-development. }\end{array}$ \\
\hline $\begin{array}{l}\text { Therioaphis trifolii } \\
\text { maculata }^{8} \text { (Jiang and Miles, } \\
\text { 1993) }\end{array}$ & $\begin{array}{l}\text { Medicago sativum } \\
\text { Fabaceae }\end{array}$ & $\begin{array}{l}\text { Increased ROS production inferred from discoloration } \\
\text { around stylet sheath and cell walls; increased SOD } \\
\text { activity; increased } \mathrm{O}_{2}^{-} \text {as inferred from reduction of } \\
\text { cytochrome c by leaf extracts. }\end{array}$ & $\begin{array}{l}\text { Observations at } 15,60 \text {, and } 90 \text { min after infestation. } \\
\text { Putative } \mathrm{O}_{2}^{-} \text {accumulation detected at similar levels at } \\
\text { all time points. }\end{array}$ \\
\hline
\end{tabular}

${ }^{*}$ Aphid species that cause marked morphological alterations or other severe, diagnostic symptoms are in bold.

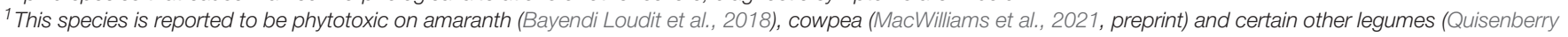
and $\mathrm{Ni}, 2007$ ), but its status on soybean is not to our knowledge reported in published literature.

${ }^{2}$ Phytotoxic symptoms described in Borowiak-Sobkowiak et al. (2016).

${ }^{3}$ Symptoms described in Durak et al. (2019).

${ }^{4}$ Symptoms described by Kmieć and Kot (2021).

5 Symptoms described by Kot and Kmieć (2020).

${ }^{6}$ Symptoms described in numerous sources, including Ryan et al. (1990).

${ }^{7}$ Symptoms described in Kmieć et al. (2018).

${ }^{8}$ Symptoms described in Madhusudhan and Miles (1998) and Goggin et al. (2017).

Buchnera aphidicola, and applying this protein to Arabidopsis foliage induces ROS accumulation and other markers of pathogen-triggered immune responses (Chaudhary et al., 2014). Thus, this microbe-associated molecular pattern (MAMP) could potentially mediate ROS induction by aphids in vivo.

Conversely, aphids have also been shown to produce salivary proteins that inhibit ROS induction, including Mp10 and Mp55 from the green peach aphid and ApHRC from pea aphids. Transient expression of Mp10 in plant tissues inhibits the oxidative burst elicited by the common bacterial MAMP flagellin (Bos et al., 2010), and a preprint reports that it also suppresses ROS induction in response to aphid extracts (Drurey et al., 2019). Moreover, ectopic expression of Mp55 or ApHRC in host plants inhibits $\mathrm{H}_{2} \mathrm{O}_{2}$ induction in response to aphid infestation (Elzinga et al., 2014; Wang et al., 2020).

The abundance of aphid salivary proteins that inhibit ROS induction may also be modulated by symbionts. In pea aphids, the facultative symbiont Serratia symbiotica promotes expression of the aphid salivary protein ApHRC, which suppresses ROS accumulation in barrel medic (Medicago truncatula). Pea aphids without S. symbiotica induce ROS, whereas pea aphids with S. symbiotica do not; moreover, silencing ApHRC expression in aphids with S. symbiotica results in ROS induction, and overexpression of ApHRC in plant tissues reverses this effect (Wang et al., 2020).

In summary, evidence from multiple systems indicate that (1) plants actively generate ROS in response to aphids; (2) certain aphid effectors trigger the ROS response while other effectors inhibit it; and (3) aphid symbionts can influence ROS induction by producing MAMPs and also by influencing the expression of aphid-encoded effectors.

\section{CHARACTERISTICS OF THE REACTIVE OXYGEN SPECIES RESPONSE TO APHIDS}

\section{Which Reactive Oxygen Species Accumulate in Response to Aphid Infestation?}

Studies in a diverse range of experimental systems indicate that aphid infestation induces ROS accumulation (Tables 1, 2). An early study of alfalfa (Medicago sativum) challenged with the spotted alfalfa aphid suggested that aphids induce $\mathrm{O}_{2}{ }^{-}$based on the ability of leaf extracts to reduce cytochrome c (Jiang and Miles, 1993). Moreover, direct histological detection of $\mathrm{O}_{2}{ }^{-}$ has since shown that aphid infestation induces this ROS in a gymnosperm (Thuja orientalis), as well as in at least four families of angiosperms (Asparagaceae, Asteraceae, Fabaceae, and Poaceae; Tables 1, 2). The majority of studies of ROS generation in response to aphids, however, have focused on hydrogen peroxide $\left(\mathrm{H}_{2} \mathrm{O}_{2}\right)$, perhaps because the relatively long half-life and lower toxicity of this ROS allow higher titers and longer persistence, facilitating detection. Aphid-responsive $\mathrm{H}_{2} \mathrm{O}_{2}$ accumulation has been demonstrated in at least 22 plant species in eight plant families, including both monocots and dicots (Tables 1, 2). Many of these studies also reported increases in markers of oxidative stress such as lipid peroxidation products, and observed changes in the expression or enzyme activities of pro- and antioxidants (Tables 1, 2). For example, ROS accumulation was often associated with increased peroxidase activity and with an initial decrease in antioxidants such as superoxide dismutase or catalase followed by a later increase in antioxidant activities (e.g., Łukasik et al., 2017; Woźniak et al., 2019). Thus, ROS accumulation is part of a coordinated 
TABLE 2 | Comparison of ROS and NO induction in compatible and incompatible interactions.

\begin{tabular}{|c|c|c|}
\hline Aphid species* & Plant species & Redox response to aphids \\
\hline $\begin{array}{l}\text { Acyrthosiphon pisum } \\
\text { (Wang et al., 2020) }\end{array}$ & $\begin{array}{l}\text { Medicago } \\
\text { truncatula } \\
\text { Fabaceae }\end{array}$ & $\begin{array}{l}\text { Increased } \mathrm{H}_{2} \mathrm{O}_{2} \text {. Compared to uninfected aphids, } \\
\text { aphids with the facultative symbiont Serratia symbiotica } \\
\text { fed more and induced less } \mathrm{H}_{2} \mathrm{O}_{2} \text { accumulation. }\end{array}$ \\
\hline $\begin{array}{l}\text { Aphis glycines } \\
\text { (Yao et al., 2020) }\end{array}$ & $\begin{array}{l}\text { Glycine max } \\
\text { Fabaceae }\end{array}$ & $\begin{array}{l}\text { Increased } \mathrm{H}_{2} \mathrm{O}_{2} \text { and CAT expression in response to } \\
\text { aphids in a susceptible (S) cultivar, but not in two } \\
\text { resistant }(\mathrm{R}) \text { cultivars. }\end{array}$ \\
\hline $\begin{array}{l}\text { Diuraphis noxia }{ }^{\mathbf{1}} \\
\text { (Moloi and van der Westhuizen, } \\
\text { 2014) }\end{array}$ & $\begin{array}{l}\text { Triticum aestivum } \\
\text { Poaceae }\end{array}$ & $\begin{array}{l}\text { Increased nitric oxide (NO) and nitrate reductase activity } \\
\text { in a } \mathrm{R} \text { cultivar but not a } \mathrm{S} \text { cultivar. }\end{array}$ \\
\hline $\begin{array}{l}\text { D. noxia } \\
\text { Botha et al., } 2014\end{array}$ & T. aestivum & $\begin{array}{l}\mathrm{H}_{2} \mathrm{O}_{2} \text { accumulation observed in infested cultivars with } \\
\text { antibiotic }(D n 1) \text { or antixenotic (Dn5) resistance, but not } \\
\text { in a S or tolerant (Dn2) cultivar. POX induction was also } \\
\text { observed in } \mathrm{R} \text { but not tolerant cultivars. }\end{array}$ \\
\hline
\end{tabular}

\section{D. noxia \\ (Berner and van der \\ Westhuizen, 2010)}

\section{D. noxia}

(Moloi and Van Der Westhuizen, 2006)

Macrosiphoniella sanbourni (Sun et al., 2016)

Macrosiphum euphorbiae (Martinez de llarduya et al., 2003)

Melanaphis sacchari ${ }^{2}$ (Pant

M. sacchari (Shao et al., 2019) S. bicolor

Myzus persicae ${ }^{¥}$ (Guo et al., Nicotiana 2020) benthamiana Solanaceae

M. persicae, Myzus cerasi, and Rhopalosiphum padi

\section{M. persicae ${ }^{£}$ (Lei et al., 2014) A. thaliana}

M. persicae (Sun et al., 2020) Capsicum

\section{baccatum} Solanaceae

Sitobion avenae (Czerniewicz et al., 2017)

\section{Triticosecale Wittm.}

Poaceae and Huang, 2021) (Jaouannet et al., 2015)

Increased $\mathrm{H}_{2} \mathrm{O}_{2}, \mathrm{POD}$, and $\mathrm{SOD}$ in response to aphids in a $\mathrm{R}$ but not $\mathrm{S}$ genotype; eliminated by an inhibitor of xanthine oxidase in peroxisome.

$\mathrm{H}_{2} \mathrm{O}_{2}$, NADPH oxidase activity, and POX increased in response to aphids more strongly in a $\mathrm{R}$ than a $\mathrm{S}$ genotype. Accumulation was blocked by an inhibitor of NADPH oxidase.

$\mathrm{H}_{2} \mathrm{O}_{2}, \mathrm{O}_{2}^{-}$, and a marker of lipid peroxidation all increased in response to aphid infestation in both a susceptible cultivar of chrysanthemum ( $D$. nankingense) and a related species that is resistant to aphids ( $A$. vulgaris).

Increased $\mathrm{H}_{2} \mathrm{O}_{2}$ in response to aphids in both $\mathrm{R}$ and $\mathrm{S}$ genotypes.

Increased $\mathrm{H}_{2} \mathrm{O}_{2}$ and expression of genes encoding SOD, APX, CATs, and glutathione S-transferases (GSTS) in a $\mathrm{R}$ cultivar. Initial decrease in $\mathrm{H}_{2} \mathrm{O}_{2}$ followed by a delayed increase in the $\mathrm{S}$ cultivar. For both infested and uninfested treatments, $\mathrm{H}_{2} \mathrm{O}_{2}$ was higher in $\mathrm{R}$ than $\mathrm{S}$ at all time points.

Increased $\mathrm{H}_{2} \mathrm{O}_{2}$, and decreased APX and POX activity. $\mathrm{H}_{2} \mathrm{O}_{2}$ induction was more rapid in $\mathrm{R}$ than $\mathrm{S}$ plants, and higher in $\mathrm{R}$ than $\mathrm{S}$ at all time points.

Increased $\mathrm{H}_{2} \mathrm{O}_{2}$, and increased expression of a gene encoding NADPH oxidase $(R b o h D)$ in response to a non-host-adapted aphid lineage with high expression levels of the elicitor cathepsin B3. A host-adapted lineage with lower cathepsin B3 expression did not induce these responses. Transient expression of cathepsin $\mathrm{B} 3$ in plant tissues also induced $\mathrm{H}_{2} \mathrm{O}_{2}$. Increased $\mathrm{H}_{2} \mathrm{O}_{2}$, but downregulation of genes associated with ROS metabolism.

Increased $\mathrm{H}_{2} \mathrm{O}_{2}$ in local but not systemic leaves of the bik1 mutant, but not in the more susceptible wild-type control Col-0.

Increased $\mathrm{H}_{2} \mathrm{O}_{2}$ in response to an avirulent aphid population. Virulent aphids did not induce $\mathrm{H}_{2} \mathrm{O}_{2}$, and decreased levels induced by avirulent aphids.

. $\mathrm{H}_{2} \mathrm{O}_{2}$ was induced by aphid infestation in a $\mathrm{R}$ and a S cultivar. $\mathrm{O}_{2}{ }^{-}$increased in a $\mathrm{R}$ cultivar and decreased in a S cultivar. The $\mathrm{R}$ line also showed earlier and stronger induction of phenolic compounds which could have antioxidant activity.

S. avenae and $R$. padi (Łukasik Triticosecale Wittm. Increased $\mathrm{H}_{2} \mathrm{O}_{2}$ in response to both aphid species, and Goławska, 2019)

\section{Timing of ROS response}

$6 \mathrm{~h}$ after infestation or infiltration with aphid saliva.

Observations at 24, 48 and 96 h. $\mathrm{H}_{2} \mathrm{O}_{2}$ elevated at $96 \mathrm{~h}$ after infestation.

Observations at 0, 3, 6, 9, 24 and $48 \mathrm{~h}$. NO first detected at $3 \mathrm{~h}$ after infestation, and peaked at $9 \mathrm{~h}$.

Observations of $\mathrm{H}_{2} \mathrm{O}_{2}$ at $6 \mathrm{~d}$ after infestation.

Observations from 2-48 h after infestation. $\mathrm{H}_{2} \mathrm{O}_{2}$ increased at $8-48 \mathrm{~h}$, with the highest levels $\sim 16 \mathrm{~h}$ and $48 \mathrm{~h}$.

Observations at 3, 6, 9, 12, 24 and 48 h. $\mathrm{H}_{2} \mathrm{O}_{2}$ increased at 3-24 h after infestation and returned to normal at $48 \mathrm{~h}$.

Observations at 3, 6, 12, 24, 48, and $168 \mathrm{~h} . \mathrm{H}_{2} \mathrm{O}_{2}$ and $\mathrm{O}_{2}^{-}$were elevated in infested plants at all time points. $\mathrm{H}_{2} \mathrm{O}_{2}$ reached it maximum levels at $6 \mathrm{~h}$ in the $\mathrm{R}$ species and $72 \mathrm{~h}$ in the $\mathrm{S}$ species; $\mathrm{O}_{2}^{-}$reached it maximum levels at $12 \mathrm{~h}$ in the $\mathrm{R}$ species and $72 \mathrm{~h}$ in the $\mathrm{S}$ species. Observations at $3,6,12$, and 24 h. $\mathrm{H}_{2} \mathrm{O}_{2}$ detected at $24 \mathrm{~h}$.

Observations at 3, 6, 9, and 12 days after infestation. Infestation induced an increase in $\mathrm{H}_{2} \mathrm{O}_{2}$ at all time points in a resistant $(\mathrm{R})$ cultivar, with the highest accumulation at 3 days. In the $\mathrm{S}$ cultivar, $\mathrm{H}_{2} \mathrm{O}_{2}$ in infested plants decreased relative to uninfested controls at 3,6 , and 9 days, and increased at 12 days.

Observations at 24, 48, 72, and $96 \mathrm{~h}$. Infestation induced $\mathrm{H}_{2} \mathrm{O}_{2}$ at 24 and $48 \mathrm{~h}$ in a $\mathrm{R}$ cultivar, and at $48 \mathrm{~h}$ in a $\mathrm{S}$ cultivar.

Observations of responses to aphids at $24 \mathrm{~h}$, and responses to transient in planta cathepsin B3 expression at $48 \mathrm{~h}$.

Observations at 3, 6, 12, and 24 h. All 3 aphid species induced $\mathrm{H}_{2} \mathrm{O}_{2}$ at 3- and $24 \mathrm{~h}$. The $3 \mathrm{~h}$ peak was stronger in response to $M$. persicae than to $R$. padi or $M$. cerasi, whereas the $24 \mathrm{~h}$ peak was much stronger in response to $R$. padi or $M$. cerasi than $M$. persicae Observations at $3,6,12$, and $24 \mathrm{~h} . \mathrm{H}_{2} \mathrm{O}_{2}$ accumulated at all time points in the bik 1 mutant.

Observations at 72 and $142 \mathrm{~h}$. Significant increase $72 \mathrm{~h}$ after infestation w/avirulent aphids; $\mathrm{H}_{2} \mathrm{O}_{2}$ persists even after an additional $72 \mathrm{~h}$ without aphids.

Observations at 24 and 48 h. $\mathrm{H}_{2} \mathrm{O}_{2}$ was elevated at $24 \mathrm{~h}$ in a $\mathrm{R}$ cultivar and at $48 \mathrm{~h}$ in a S cultivar. $\mathrm{O}_{2}^{-}$was elevated at both time points in a R cultivar, and decreased in a $\mathrm{S}$ cultivar at $48 \mathrm{~h}$.

Observations at 6, 24, 48, and 96 h. In a R cultivar, $\mathrm{H}_{2} \mathrm{O}_{2}$ increased in response at all time points, with the highest levels at 24 and $48 \mathrm{~h}$. In S, $\mathrm{H}_{2} \mathrm{O}_{2}$ increased at 24,48 , and $96 \mathrm{~h}$. 
TABLE 2 | (Continued)

\begin{tabular}{|c|c|c|c|}
\hline Aphid species* & Plant species & Redox response to aphids & Timing of ROS response \\
\hline $\begin{array}{l}\text { S. avenae and } R \text {. padi, } \\
\text { (Sytykiewicz, 2016) }\end{array}$ & $\begin{array}{l}\text { Zea mays } \\
\text { Poaceae }\end{array}$ & $\begin{array}{l}\text { Increased } \mathrm{H}_{2} \mathrm{O}_{2} \text { and } \mathrm{NADPH} \text { oxidase activity in } \\
\text { response to both aphid species, with stronger } \mathrm{H}_{2} \mathrm{O}_{2} \\
\text { induction in a } \mathrm{R} \text { cultivar than a S cultivar. } \\
\text { Aphid-responsive } \mathrm{H}_{2} \mathrm{O}_{2} \text { accumulation was eliminated } \\
\text { by an inhibitor of } \mathrm{NADPH} \text { oxidases. }\end{array}$ & $\begin{array}{l}\text { Observations at } 4 \text { and } 24 \mathrm{~h} ; \mathrm{H}_{2} \mathrm{O}_{2} \text { induction seen at } \\
\text { both time points. }\end{array}$ \\
\hline $\begin{array}{l}\text { S. avenae and R. padi, } \\
\text { (Sytykiewicz, 2015) }\end{array}$ & Zea mays & $\begin{array}{l}\text { Both aphid species induced } \mathrm{H}_{2} \mathrm{O}_{2} \text {, and higher } \\
\text { infestation levels led to higher } \mathrm{ROS} \text { levels. A highly R } \\
\text { cultivar accumulated more } \mathrm{H}_{2} \mathrm{O}_{2} \text { than a moderately } \\
\text { resistant cultivar, and a moderately } \mathrm{R} \text { cultivar had more } \\
\mathrm{H}_{2} \mathrm{O}_{2} \text { than a susceptible cultivar at both } 24 \text { and } 48 \mathrm{~h} \text {. } \\
\text { Uninfested } \mathrm{R} \text { cultivars also had higher basal } \mathrm{H}_{2} \mathrm{O}_{2} \\
\text { levels than the S cultivar. }\end{array}$ & $\begin{array}{l}\text { Observations at } 2,4,8,24 \text {, and } 48 \mathrm{~h} . \mathrm{H}_{2} \mathrm{O}_{2} \text { increased } \\
\text { over } 2-24 \mathrm{~h} \text {, and was declining at } 48 \mathrm{~h} \text {. }\end{array}$ \\
\hline $\begin{array}{l}\text { S. avenae and R. padi, } \\
\text { (Sytykiewicz et al., 2014) }\end{array}$ & Zea mays & $\begin{array}{l}\text { Both aphid species induced } \mathrm{O}_{2}^{-} \text {and GST gene } \\
\text { expression, with higher infestation levels inducing } \\
\text { higher ROS levels. } \mathrm{O}_{2}^{-} \text {accumulation was higher in a } \mathrm{R} \\
\text { than in an } \mathrm{S} \text { cultivar, and was also higher in response to } \\
\text { R. padi than S. avenae. }\end{array}$ & $\begin{array}{l}\text { Observations at } 1,2,4,8,24,48 \text {, and } 72{\mathrm{~h} . \mathrm{O}_{2}}^{-} \\
\text {reached their maximum at } 4 \mathrm{~h} \text {, but under high } \\
\text { infestation levels, remained elevated at } 48 \mathrm{~h} . \mathrm{In} \\
\text { response to } R \text {. padi, } \mathrm{O}_{2}^{-} \text {levels increased more rapidly } \\
\text { in the } \mathrm{R} \text { than the } \mathrm{S} \text { cultivar. }\end{array}$ \\
\hline
\end{tabular}

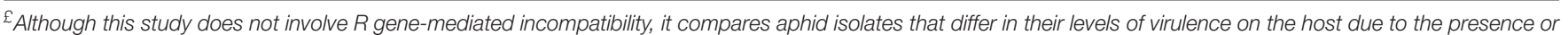
absence of a secondary symbiont.

*Aphid species that cause marked morphological alterations or other severe, diagnostic symptoms are in bold.

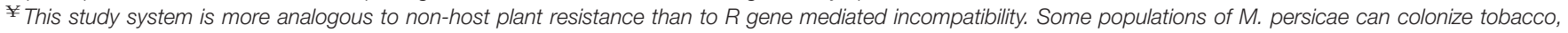

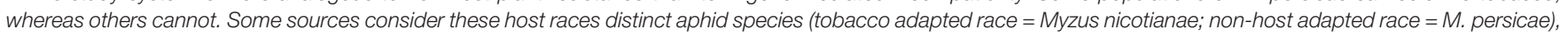
although molecular evidence for speciation is lacking (Clements et al., 2000).

$€ T$ is study system does not involve $R$ gene mediated incompatibility, but instead focuses on a null mutation (bik1) that confers aphid resistance.

${ }^{1}$ Symptoms described in numerous sources, including Burd and Burton (1992).

2Symptoms described in Singh et al. (2004) and Pant and Huang (2021).
}

redox response in the plant. This oxidative response was observed in both resistant and susceptible plants in response to a diversity of aphids with widely varying effects on their hosts, ranging from species that typically do not cause obvious, diagnostic symptoms (e.g., M. persicae on Arabidopsis, or Sitobion avenae on cereals) to species that cause strong phytotoxic effects such galling (Tetraneura ulmi, Pemphigus spp.), leaf rolling (D. noxia), malformation of new growth (Brachycorynella asparagi), discoloration, necrosis, or even in some cases death of the entire plant (Melanaphis sacchari, S. graminum, and T. trifolii maculata). Thus, it is clear that aphids can induce $\mathrm{O}_{2}{ }^{-}$and $\mathrm{H}_{2} \mathrm{O}_{2}$, and that ROS induction is a widely conserved response in both compatible and incompatible interactions with a diverse array of aphids (Tables 1, 2).

The prevalence of oxidative responses to aphids also suggests that it would be worthwhile to test for the presence of other reactive species beyond $\mathrm{H}_{2} \mathrm{O}_{2}$ and $\mathrm{O}_{2}{ }^{-}$. Recent advances in the use of luminescent probes and reporter gene systems facilitate the detection of multiple ROS (Ortega-Villasante et al., 2018), and while a recent study did not detect any effects of the pea aphid on hydroxyl radical $(\mathrm{OH})$ abundance in pea plants (Łukaszewicz et al., 2021), preliminary data suggests that the green peach aphid may induce singlet oxygen $\left({ }^{1} \mathrm{O}_{2}\right)$ accumulation in Arabidopsis (Fischer, 2021). In addition, Russian wheat aphid infestation on wheat induces accumulation of nitric oxide, a reactive nitrogen species that interacts with ROS to regulate other stress responses (Moloi and van der Westhuizen, 2014; Moloi et al., 2014).

Together, these studies indicate that aphids induce an oxidative response associated with multiple reactive species, and further work is merited to characterize the full range of molecules involved and their impacts on plant defense.

\section{When Are Reactive Oxygen Species Produced in Response to Aphids?}

Our current understanding of the temporal dynamics of ROS responses to aphids is somewhat limited and suggests considerable variation among different plant-aphid interactions. The small number of studies that have measured ROS levels within the first hour after aphid infestation (Argandoña et al., 2001; Xu et al., 2021) or treatment with aphid extracts (Prince et al., 2014) indicate that ROS accumulation can occur within minutes. Moreover, time course studies focused on the early hours of the interaction suggest that this ROS response may have a biphasic pattern similar to the oxidative burst elicited by many plant pathogens (Prince et al., 2014; Jaouannet et al., 2015; Xu et al., 2021). However, most studies have measured ROS at a small number of timepoints between 2 and $96 \mathrm{~h}$ after infestation (Tables 1, 2). Of the time series conducted within this range, the majority suggest a transient ROS response that peaks on or before $24 \mathrm{~h}$ and then declines, often returning to baseline levels 3-4 days after treatment (Moloi and Van Der Westhuizen, 2006; Moloi and van der Westhuizen, 2014; Ren et al., 2014; Sytykiewicz, 2015; Mai et al., 2016, 2017; Łukasik et al., 2017; Shao et al., 2019; Woźniak et al., 2019). Certain time series studies, however, did not detect significant increases in ROS until well after $24 \mathrm{~h}$ (Kerchev et al., 2012; Yao et al., 2020), or observed ROS levels that peaked after $24 \mathrm{~h}$ and/or continued to increase steadily in the days following infestation (Borowiak-Sobkowiak et al., 2016; Sun et al., 2016; Zhang et al., 2019). In one of the longest time series studies, $\mathrm{O}_{2}{ }^{-}$ 
induction in arborvitae ( $T$. orientalis) by the cypress pine aphid (Cinara tujafilina) persisted even at 2 weeks after infestation (Durak et al., 2019). Thus, ROS induction by aphids can in some cases be slow and/or quite persistent.

In general, these delayed or persistent ROS responses were observed in compatible interactions, often with aphid species such as the greenbug, the cypress pine aphid, the asparagus aphid (B. asparagi), and the poplar spiral gall aphid (Pemphigus spyrothecae) that induce marked phytotoxic symptoms (Table 1). Consistent with this pattern, in a comparison of sorghum genotypes that were resistant or susceptible to the phytotoxic sugarcane aphid (M. sacchari), aphid challenge on resistant plants induced an earlier oxidative response that peaked at 3 days and then declined, whereas $\mathrm{H}_{2} \mathrm{O}_{2}$ levels in the susceptible cultivar initially decreased in response to aphids and then increased at 12 days post-infestation, when extensive aphid damage was present (Pant and Huang, 2021). However, heightened $\mathrm{H}_{2} \mathrm{O}_{2}$ levels have also been observed in an aphid-resistant chili pepper cultivar 6 days after challenge with avirulent green peach aphids even when aphids were removed 3 days prior (Sun et al., 2020); furthermore, a sorghum genotype resistant to the sugarcane aphid was reported to have constitutively high $\mathrm{H}_{2} \mathrm{O}_{2}$ in comparison to a susceptible genotype even in the absence of infestation (Shao et al., 2019). Therefore, certain incompatible interactions also appear to involve long-term ROS accumulation. In addition, the limited number of studies that have utilized more than one probe for ROS detection indicate that $\mathrm{H}_{2} \mathrm{O}_{2}$ and $\mathrm{O}_{2}{ }^{-}$can in some cases differ from one another in their onset and persistence (Mai et al., 2013, 2017; Sun et al., 2016; Czerniewicz et al., 2017), and that the timing of the oxidative response to aphids also varies among subcellular compartments (Xu et al., 2021).

In summary, aphid-responsive ROS can occur within minutes and persist for days or even weeks after infestation. Resistance is typically associated with rapid ROS responses and persistent ROS accumulation is often associated with aphid damage; however, exceptions exist to these generalizations, and additional, more detailed studies on the temporal and spatial dynamics of ROS are needed in order to establish correlations with defense mechanisms or symptom development. The in planta expression of luminescent probes that can reversibly respond to ROS is a particularly promising approach to study the temporal dynamics of the oxidative response to aphids because it can allow continuous, non-destructive monitoring of ROS accumulation in live tissues (Xu et al., 2021).

\section{Where and How Are Reactive Oxygen Species Generated in Response to Aphids?}

Our current understanding of the spatial dynamics of ROS induction by aphids is even more limited than our knowledge of the temporal patterns of this response. Although the saliva of certain aphids has been reported to translocate within the plant (Madhusudhan and Miles, 1998) and other biotic and abiotic stresses have been shown to trigger systemic ROS signaling (Miller et al., 2009), few studies have explored the potential for long-distance oxidative responses to aphids. Lei et al. (2014) compared $\mathrm{H}_{2} \mathrm{O}_{2}$ levels in adjacent Arabidopsis leaves with and without green peach aphid infestation and saw ROS accumulation only in infested leaves. However, Woźniak et al. (2019) reported that aphid infestation on asparagus foliage induced lipid peroxidation and modified superoxide dismutase and peroxidase activities in roots as well as leaves, suggesting that aphid infestation can have systemic effects on plant redox balance. Thus, further studies are warranted to characterize the spatial patterns of aphid-responsive ROS induction throughout the host plant.

Additional studies of ROS localization are also needed at the cellular and subcellular levels because current evidence suggests that aphid infestations induce ROS accumulation both extraand intracellularly, via multiple biosynthetic mechanisms. In aphid-infested pea foliage, $\mathrm{H}_{2} \mathrm{O}_{2}$ was observed in the apoplast in association with the cell walls of epidermal cells (Woźniak et al., 2019). Potentially, the extracellular $\mathrm{H}_{2} \mathrm{O}_{2}$ pool could result from generation of $\mathrm{O}_{2}{ }^{-}$by plasma membrane-associated $\mathrm{NADPH}$ oxidases and conversion of $\mathrm{O}_{2}{ }^{-}$to $\mathrm{H}_{2} \mathrm{O}_{2}$ by superoxide dismutases. This mechanism of ROS generation drives the oxidative burst associated with many forms of pathogen resistance in plants (Wang et al., 2018). Experimental inhibition of NADPH oxidases has been reported to block aphid-responsive $\mathrm{H}_{2} \mathrm{O}_{2}$ generation in wheat (Triticum aestivum), Arabidopsis, and corn (Zea mays), supporting the hypothesis that NADPH oxidases mediate extracellular ROS accumulation in response to aphids (Moloi and Van Der Westhuizen, 2006; Prince et al., 2014; Jaouannet et al., 2015; Sytykiewicz, 2016). Interestingly, aphid-responsive ROS accumulation in Arabidopsis appears to depend more heavily on the NADPH oxidase RbohF than on its homolog RbohD, whereas $\mathrm{RbohD}$ is primarily responsible for pathogen-inducible ROS accumulation (Jaouannet et al., 2015). Thus, different NADPH oxidases may be specialized to respond to different stresses. $\mathrm{H}_{2} \mathrm{O}_{2}$ in the apoplast also could be generated by cell wall peroxidases, as is seen in certain plant-pathogen interactions (O'Brien et al., 2012); notably, multiple studies have observed increases in peroxidase activity in response to aphid infestation (Table 1).

In addition to arising in the apoplast, $\mathrm{H}_{2} \mathrm{O}_{2}$ could originate intracellularly and be exported from the cell; consistent with this, M. persicae infestation induces sustained $\mathrm{H}_{2} \mathrm{O}_{2}$ efflux in tobacco (Nicotiana tabacum) (Ren et al., 2014). Although few studies have examined the subcellular localization of oxidative responses to aphids, we have recently shown that $M$. persicae infestation on Arabidopsis causes rapid and sustained oxidation in the cytosol, peroxisomes, and chloroplasts (Fischer, 2021; Xu et al., 2021). The timing of these intracellular oxidative responses suggests that they are distinct from apoplastic ROS accumulation (Xu et al., 2021). M. persicae infestation on potato (S. tuberosum) also upregulates expression of a peroxisomal catalase and a chloroplastic SOD, suggesting an impact of aphids on intracellular redox balance (Kerchev et al., 2012). Moreover, an inhibitor of peroxisomal xanthine oxidase blocks $\mathrm{H}_{2} \mathrm{O}_{2}$ induction by $D$. noxia in wheat (Berner and van der Westhuizen, 2010).

Together, these studies suggest that both extracellular and intracellular sources of ROS contribute to the oxidative response 
to aphid infestation. Consistent with this hypothesis, $\mathrm{H}_{2} \mathrm{O}_{2}$ was detected in the cell walls of aphid-infested asparagus (Asparagus officinalis) at early time points and low infestation levels, whereas it appeared to have a primarily cytosolic location at later time points and in samples that had higher ROS levels and more extensive symptom development due to the use of higher infestation levels or more susceptible life stages of the host plant (Woźniak et al., 2019). Similarly, our observations in Arabidopsis suggest that apoplastic ROS accumulation is limited to the early hours of the response, whereas intracellular ROS generation in the peroxisome and cytosol may be more persistent (Xu et al., 2021).

In short, it appears that different extra- and intercellular compartments contribute to different phases of the oxidative response, and further studies are warranted to investigate how these different sources of ROS impact the outcome of the plantaphid interaction.

\section{What Causes Variation in Reactive Oxygen Species Generation in Response to Aphids?}

Although ROS induction has been observed in a wide array of plant-aphid interactions, this response also displays considerable variability. The onset and duration of ROS accumulation varies widely in different studies (Tables 1, 2). Moreover, not all studies that have measured ROS have detected an increase in response to aphids; for example, using 3,3'-diaminobenzidine (DAB) staining, Kuśnierczyk et al. (2008) could not detect $\mathrm{H}_{2} \mathrm{O}_{2}$ accumulation in Arabidopsis in response to the cabbage aphid, Brevicoryne brassicae, even though they observed induction of numerous genes related to $\mathrm{H}_{2} \mathrm{O}_{2}$ signaling. Different ROS detection methods vary in how sensitive and quantitative they are, which can contribute to study-to-study variation (Queval et al., 2008). Study-to-study variation likely also reflects a variety of biological sources of variability. Side-by-side comparisons have revealed that the magnitude of ROS induction varies depending upon the aphid species (Sytykiewicz et al., 2014; Jaouannet et al., 2015; Zhang et al., 2019; Kmieć and Kot, 2021), the aphid biotype (Guo et al., 2020; Sun et al., 2020), the plant cultivar (Table 2), plant age (Borowiak-Sobkowiak et al., 2016), location of the aphid infestation on the plant (Kmieć and Kot, 2021), and aspects of the experimental design such as infestation levels and timing of measurement (Borowiak-Sobkowiak et al., 2016; Mai et al., 2017; Durak et al., 2019; Łukasik and Goławska, 2019). For example, when different infestation levels were compared on soybean, asparagus, and wheat, ROS levels peaked more rapidly in plants challenged with higher aphid densities (BorowiakSobkowiak et al., 2016; Mai et al., 2017; Durak et al., 2019; Łukasik and Goławska, 2019).

Most of all, the scattered and asynchronous nature of aphid feeding sites poses special experimental challenges. In comparison to bacteria or other pathogens that can be infiltrated into leaves at high concentrations, even very high numbers of aphids establish a fairly low concentration of feeding sites on infested tissues, resulting in far fewer sites of cellular interaction. Moreover, these cellular interactions are highly asynchronous because aphids do not all initiate feeding at the same time or feed for the same duration, and can initiate new feeding sites at any time. As a result, investigators have limited experimental control over the density of feeding sites and the stage(s) of the interaction that are being sampled. This can limit signal strength, increase random sample-to-sample variation, and make it difficult to pinpoint the timing of transient responses.

We propose that a finer-scale kinetic analysis of aphidresponsive ROS accumulation is warranted, especially since the timing and localization of oxidative responses impact their potential contributions to defense. Highly sensitive luminescent probes for ROS detection could potentially be applied to study the spatial and temporal dynamics of the ROS response at individual feeding sites, and could open new avenues of research in hostplant resistance to aphids.

\section{WHY? EFFECTS OF REACTIVE OXYGEN SPECIES ACCUMULATION ON RESISTANCE OR SUSCEPTIBILITY TO APHIDS}

\section{Correlations Between Reactive Oxygen Species and Resistance}

One approach to assess the functional significance of ROS in plant-aphid interactions is to compare the timing and magnitude of ROS accumulation in plant-aphid combinations with varying degrees of compatibility (Table 2). To this end, numerous studies have examined compatible and incompatible interactions governed by resistance genes in host plants and effector genes in aphids; in addition, a smaller number of studies have examined non-host resistance (Jaouannet et al., 2015) and gain-of-function resistance resulting from mutagenesis (Lei et al., 2014). Of 14 studies that compared ROS accumulation in aphid-resistant and aphid-susceptible plant genotypes, 12 of these studies observed stronger and/or faster ROS accumulation on the resistant plants, with ROS accumulation in some cases being entirely absent in the susceptible varieties (Table 2). For example, in wheat challenged with the Russian wheat aphid, extensive $\mathrm{H}_{2} \mathrm{O}_{2}$ accumulation was observed in resistant but not in tolerant or susceptible genotypes (Botha et al., 2014). This oxidative response occurred in both antibiotic and antixenotic forms of resistance, but was stronger in plants with the $D n 1$ gene for antibiosis, possibly because Dn1 mediates a strong hypersensitive response (Botha et al., 2014). This and other studies in Table 2 suggest that ROS may contribute to multiple resistance pathways, and highlight the need for more mechanistic studies to determine how ROS impact plant defenses against aphids.

Other evidence for a correlation between ROS and plant defense comes from studies of aphid biotypes, host races, or species that vary in their ability to colonize the same host. Avirulent green peach aphids induced persistent $\mathrm{H}_{2} \mathrm{O}_{2}$ accumulation in a resistant cultivar of pepper (Capsicum baccatum), but a virulent biotype did not, and could reverse prior ROS induction by avirulent aphids (Sun et al., 2020). Moreover, in comparison to a lineage of the green peach aphid 
that could colonize Nicotiana benthamiana, a lineage that was not adapted to this host induced significantly higher $\mathrm{H}_{2} \mathrm{O}_{2}$ levels in tobacco and expressed higher levels of the elicitor cathepsin B3 (Guo et al., 2020). Similarly, aphid species that could not colonize Arabidopsis (Rhopalosiphum padi) or that colonized it only weakly (Myzus cerasi) induced stronger $\mathrm{H}_{2} \mathrm{O}_{2}$ accumulation at $24 \mathrm{~h}$ than $M$. persicae, which is well-adapted to Arabidopsis (Jaouannet et al., 2015). Interestingly, at $3 \mathrm{~h} \mathrm{M}$. persicae actually induced stronger $\mathrm{H}_{2} \mathrm{O}_{2}$ accumulation than $R$. padi or M. cerasi, but it also more strongly downregulated genes associated with ROS metabolism.

Together, these studies suggest that strong ROS responses within the first $24 \mathrm{~h}$ are correlated with incompatibility, and that the ability of aphids to suppress these ROS responses promote compatibility. However, there are some exceptions to this generalization. The soybean aphid induced ROS accumulation at $96 \mathrm{~h}$ in a susceptible soybean cultivar but not in a resistant genotype, indicating that ROS accumulation is not necessarily associated with all forms of aphid resistance (Yao et al., 2020). Furthermore, a direct comparison of the phytotoxic greenbug S. graminum and a non-phytotoxic species (the English grain aphid, $S$. avenae) on susceptible winter wheat ( $T$. aestivum) revealed earlier, stronger, and more persistent ROS accumulation in response to the phytotoxic species, suggesting a correlation between ROS generation and symptom development (Zhang et al., 2019). Prolonged ROS induction by other phytotoxic species such as the cypress pine aphid and the asparagus aphid was also accompanied by extensive symptom development (Borowiak-Sobkowiak et al., 2016; Durak et al., 2019).

To summarize, these studies indicate that rapid ROS induction is often correlated with aphid resistance, but that persistent ROS accumulation may in some cases cause oxidative stress, contributing to symptom development in some compatible interactions.

\section{Association With Nitric Oxide Induction}

To add support to the idea that plant defenses against aphids are associated with rapid redox reactions, there is also evidence that the reactive nitrogen species nitric oxide (NO) plays a role in plant-aphid interactions (Arnaiz et al., 2021). Pea aphids induce extracellular NO accumulation in pea in the first $48 \mathrm{~h}$ of the interaction in conjunction with induction of defensive hormones including jasmonates, salicylic acid, and ethylene (Mai et al., 2014). The Russian wheat aphid induces NO accumulation and nitrate reductase activity within $3 \mathrm{~h}$ in a resistant wheat cultivar but not in a near-isogenic susceptible cultivar (Moloi and van der Westhuizen, 2014). Exogenous treatments with a NO donor, sodium nitroprusside (SNP) reduces the intrinsic rate of increase of the Russian wheat aphid on wheat (Moloi et al., 2014) and decreases the feeding behavior and fecundity of the pea aphid on pea (Woźniak et al., 2017). Together, these results suggest that NO contributes to plant defenses against aphids. Furthermore, Russian wheat aphids also trigger accumulation of peroxynitrite, a product generated when NO reacts with $\mathrm{O}_{2}{ }^{-}$radicals (Moloi et al., 2014). This supports the hypothesis that NO interacts with ROS to regulate plant responses to aphids. ROS can induce NO synthesis, and reactive oxygen and nitrogen species react chemically and interact synergistically to promote many plant responses to biotic and abiotic stress (Wang et al., 2013; Farnese et al., 2016). For example, the interaction between $\mathrm{NO}$ and $\mathrm{H}_{2} \mathrm{O}_{2}$ mediates the hypersensitive response to pathogens and also stomatal closure in response to drought (Delledonne et al., 2001; Bright et al., 2006). Whereas ROS induce NO synthesis, NO can hamper further ROS accumulation by inhibiting NADPH oxidase activity and by promoting antioxidant activities (Farnese et al., 2016); for example, in Arabidopsis, NO enhances the activity of a cytosolic ascorbate peroxidase by $S$-nitrosylation (Yang et al., 2015). In this way NO may help fine-tune the timing of ROS responses and limit oxidative damage.

In summary, there is evidence from pea and wheat that NO contributes to plant defenses against aphids, and may interact with ROS to modulate the oxidative response.

\section{Effects of Aphid Effectors on Aphid Performance}

Since several studies have identified effectors in aphid saliva that promote or inhibit ROS accumulation in the host plant, another approach to explore the adaptive significance of the ROS response is to determine how modifying effector expression impacts aphid performance. RNA interference (RNAi) to suppress expression of the ROS elicitor cathepsin B3 increases feeding by a nonhost adapted green peach aphid lineage on N. benthamiana (Guo et al., 2020). Similarly, ectopic expression of the symbiont-derived ROS elicitor GroEL in plants reduces the fecundity of the green peach aphid and also the potato aphid, Macrosiphum euphorbiae (Chaudhary et al., 2014). In planta expression of Mp55, a salivary inhibitor of ROS induction, increases the attraction of the green peach aphid to transgenic Arabidopsis plants in choice tests (Elzinga et al., 2014). RNAi of another ROS inhibitor, Mp10, decreases green peach aphid numbers; moreover, a preprint reports that Mp10 is conserved in other plant-feeding Hemipterans such as whiteflies, psyllids, and leafhoppers, but not in carnivorous Hemipterans, suggesting that it is important to the plant-parasitic lifestyle (Drurey et al., 2019). It is important to remember that each of these salivary proteins likely has multiple impacts on plants and aphids, and so their effects on aphid fitness are not necessarily due exclusively to their impacts on ROS accumulation. Nonetheless, when taken together, the studies to date suggest that that ROS induction limits aphid feeding and reproduction, and that salivary effectors that hamper ROS induction benefit aphid fitness.

\section{Effects of Artificial Manipulation of Reactive Oxygen Species Accumulation on Aphid Performance}

The adaptive significance of ROS in plant-aphid interactions can also be investigated by experimental manipulation of ROS levels, either through direct modification of the host plant or through microbes that influence ROS levels in plants. Several studies that artificially manipulate ROS accumulation in host plants support the hypothesis that ROS play a role in limiting aphid infestations. In Arabidopsis, mutations that impair NADPH oxidase activity 
increase the survival of $R$. padi, a species that cannot reproduce on Arabidopsis, and these mutations also enhance the population growth of the green peach aphid and a related species (M. cerasi) that normally has limited ability to colonize this plant (Miller et al., 2009; Jaouannet et al., 2015). Conversely, a gain-of-function mutation in Arabidopsis that results in constitutively higher ROS accumulation decreases infestations by the green peach aphid and the cabbage aphid (B. brassicae) (Chen et al., 2014). In potato, a chemical treatment that promotes accumulation of the antioxidant ascorbic acid also increases green peach aphid numbers (Kerchev et al., 2012).

In addition, it appears that microbes associated with aphids or plants can hurt or help aphid fitness depending upon whether they enhance or suppress the ROS response in host plants. When the green peach aphid transmits Cucumber Mosaic Virus (CMV) to tobacco, the virus induces $\mathrm{H}_{2} \mathrm{O}_{2}$ accumulation in the host plant and reduces aphid feeding; the effects of CMV on aphid feeding can be eliminated by deleting the viral protein that triggers ROS induction or by suppressing NADPH oxidase activity in the plant (Guo et al., 2019). Therefore, the inhibitory effects of CMV on aphid feeding appear to be due to induction by CMV of NADPH oxidase-dependent $\mathrm{H}_{2} \mathrm{O}_{2}$ generation in the host plant. Conversely, the facultative aphid symbiont S. symbiotica enhances pea aphid feeding on barrel medic by promoting expression of a salivary protein (ApHRC) that limits ROS induction; silencing this protein increases ROS induction and decreases aphid feeding (Wang et al., 2020). Treating plants with certain plant growth-promoting rhizobacteria also causes a faster, stronger oxidative response to aphids and decreases aphid population growth (Rashid et al., 2017; Veselova et al., 2019); this finding is particularly exciting because it suggests a possible means of exploiting ROS for crop protection. Thus, manipulation of ROS levels in multiple plant-aphid interactions implicate ROS in plant defenses against aphids. However, not all such studies support this conclusion. Population growth of the green peach aphid on Arabidopsis was inhibited by a transgene that increases the antioxidant ascorbic acid in the apoplast (Rasool et al., 2017), and by loss of function of OXI1, a downstream component of $\mathrm{H}_{2} \mathrm{O}_{2}$ signaling (Shoala et al., 2018). Loss of function of catalase 2 , which converts $\mathrm{O}_{2}{ }^{-}$to $\mathrm{H}_{2} \mathrm{O}_{2}$ in the chloroplast, also decreases green peach aphid fecundity on Arabidopsis, although it is unclear whether this effect is due to decreased $\mathrm{H}_{2} \mathrm{O}_{2}$, increased $\mathrm{O}_{2}{ }^{-}$, or other possible effects of catalase activity (Rasool et al., 2019). A mutation (cpl1) that decreased the sensitivity of Arabidopsis to $\mathrm{O}_{2}{ }^{-}$also decreased plant symptom development after prolonged (14 days), heavy infestations of the green peach aphid (Thatcher et al., 2018).

Together, these reports suggest that while ROS contribute to defense in many plant-aphid interactions, aspects of the oxidative response can also facilitate aphid infestation and/or promote feeding damage in certain compatible interactions.

\section{Challenges in Studying the Adaptive Significance of Reactive Oxygen Species}

When interpreting experiments to manipulate in vivo ROS accumulation, is important to remember that pro- and

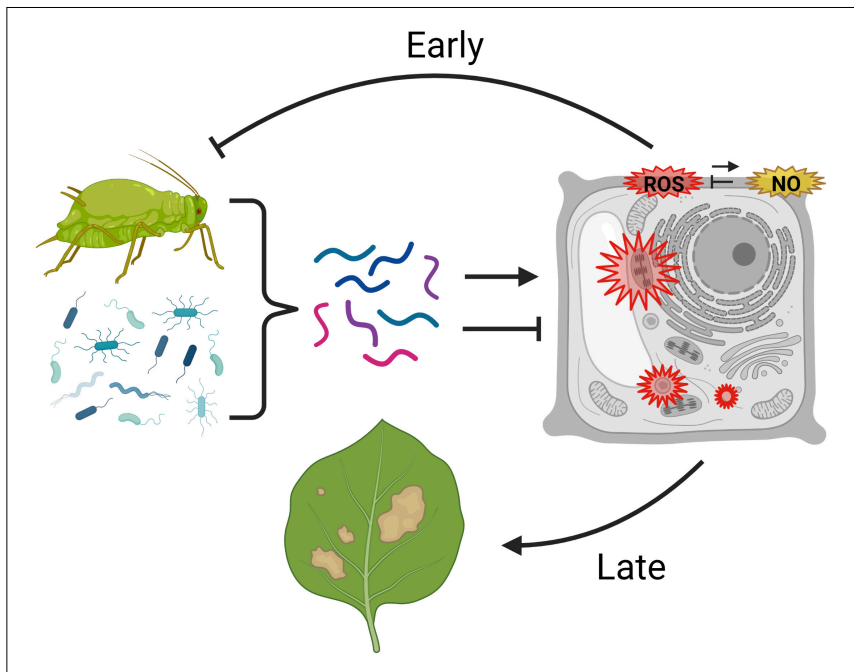

FIGURE 1 | Possible model for the roles of reactive oxygen species (ROS) and nitric oxide (NO) in plant-aphid interactions. Aphids and their microbial associates produce a combination of effectors (represented by multicolored lines) that can promote or inhibit an oxidative response in the host plant. Aphid-responsive reactive oxygen species production (ROS, in red) is known to occur in the apoplast, cytosol, chloroplast, and peroxisomes, and may potentially be modulated by nitric oxide (NO, in yellow), which also accumulates in the apoplast in response to aphids. Rapid, early ROS responses are thought to contribute to certain forms of aphid resistance, whereas delayed, persistent ROS accumulation, particularly intracellularly, may contribute to symptom development in response to infestation. This graphic was created using BioRender.

antioxidants in plants are intertwined in a complex redox signaling system (Noctor et al., 2016). For example, as noted in Tables 1, 2, ROS responses to aphid feeding are often accompanied by changes in the expression levels or activity of multiple anti- or pro-oxidant enzymes. Experiments that modify any single component in the plant redox system may have complex pleiotropic effects, or conversely, may simply be outweighed by other components with overlapping functions. Moreover, the tools that are most commonly available to manipulate ROS (chemical inhibitors, null mutations, overexpression lines, etc.) have limited capacity to modulate the important temporal and spatial dynamics of the redox response. Thus, although functional genomics and other manipulative experimental approaches have advanced our understanding of plant-aphid interactions immensely, we must exercise caution in interpreting these experiments. In the future, as our understanding of individual pro- and antioxidant systems increases, we hope that this knowledge will be integrated to provide a more comprehensive systems approach to redox responses to aphid challenge.

\section{DISCUSSION}

\section{Summary}

Over 40 years of research on a wide range of plant taxa have demonstrated that plants produce $\mathrm{O}_{2}{ }^{-}, \mathrm{H}_{2} \mathrm{O}_{2}$, and $\mathrm{NO}$ 
in response to effectors from aphids and their symbionts. Moreover, oxidative responses are common in both compatible and incompatible interactions with a wide range of aphids, including asymptomatic as well as phytotoxic species. Figure $\mathbf{1}$ summarizes a potential model for the roles of ROS in plantaphid interactions. Oxidative responses to aphids involve both apoplastic and intracellular sources of ROS, and the timing of ROS accumulation can vary from minutes to days. Although exceptions to this generalization exist, ROS accumulation in incompatible interactions is most often rapid and transient, whereas delayed, persistent ROS accumulation is most often observed in compatible interactions with phytotoxic species. In the last 10 years, advances in genomics have enabled the identification of factors in aphids and their associated microbes that influence the oxidative response in host plants. Certain effectors that induce ROS can reduce aphid performance on plants, whereas other effectors that hamper ROS induction appear to facilitate the infestation process. Likewise, several treatments that compromise the plants' ability to generate ROS, such as loss of function of NADPH oxidases, have been shown to increase susceptibility to aphids. These studies strongly suggest that ROS promote resistance in many incompatible interactions and also contribute to basal defenses that limit the extent of infestation in compatible interactions. However, evidence also exists for a role of certain components of the ROS response, such as OXI-signaling, in susceptibility and symptom development. Potentially, the oxidative response may mediate resistance in some aphid-host combinations but contribute to susceptibility in others. Another explanation that is not mutually exclusive is that even within a single plant-aphid interaction, different phases and components of the oxidative response may have differing adaptive significance. In particular, the identity of the RO species involved, the subcellular compartment in which they originate, and the speed, magnitude, and persistence of accumulation may all influence whether ROS contribute to aphid resistance or susceptibility. Further work is needed to dissect the impacts of the different phases and components of the plant redox response on levels of resistance or susceptibility to aphids.

\section{Future Directions}

New approaches to characterize and manipulate the timing and localization of specific ROS are needed for a more complete understanding of oxidative responses to aphid infestation. In particular, further studies are warranted to: (1) investigate the

\section{REFERENCES}

Ahmad, P., Jaleel, C. A., Salem, M. A., Nabi, G., and Sharma, S. (2010). Roles of enzymatic and nonenzymatic antioxidants in plants during abiotic stress. Crit. Rev. Biotech. 30, 161-175. doi: 10.3109/07388550903524243

Apel, K., and Hirt, H. (2004). Reactive oxygen species: metabolism, oxidative stress, and signal transduction. Annu. Rev. Plant Biol. 55, 373-399. doi: 10.1146/ annurev.arplant.55.031903.141701

Argandoña, V. H., Chaman, M., Cardemil, L., Muñoz, O., Zúñiga, G. E., and Corcuera, L. J. (2001). Ethylene production and peroxidase activity in aphidinfested barley. J. Chem. Ecol. 27, 53-68. doi: 10.1023/A:1005615932694 adaptive significance of ROS production in the chloroplast and other intracellular sites compared with apoplastic ROS; (2) explore the role of NO in modulating the ROS response; (3) identify the downstream effects of ROS that may mediate resistance or susceptibility, such as the potential impacts of ROS on cell walls, membrane lipids, post-translational protein modification, and global gene expression; and (4) integrate our knowledge of individual pro- and antioxidants in the plant into a more comprehensive systems-view of redox responses to aphid challenge. Research in this area is opening new horizons in agroecology; for example, it is helping to explain how and why components of the microbial community such as aphid symbionts, viruses, and plant rhizobacteria can influence plant susceptibility to aphids (Rashid et al., 2017; Guo et al., 2019; Wang et al., 2020). This research also has exciting applications for pest management such as the potential use of rhizobacteria as biocontrol agents to induce ROS-mediated aphid resistance (Veselova et al., 2019). Most of all, this field of study is important to understand plant adaptation to stresses in a changing world. Plant interactions with aphids are impacted by drought, extreme temperatures, and other harsh environmental conditions, and the plant's redox regulation, sensing, and signaling system mediates these interactive effects (Foyer et al., 2016). Indeed, this system is a nexus linking abiotic and biotic stress responses, and contributes to induced resistance, induced susceptibility, stress priming, and long-term memory (Carmody et al., 2016). Therefore, in the face of increasingly extreme and variable climactic conditions, understanding plant redox responses to aphids is critical to the future of crop protection.

\section{AUTHOR CONTRIBUTIONS}

FG and HF conceived and wrote this review article. Both authors contributed to the article and approved the submitted version.

\section{FUNDING}

This work was supported by the University of Arkansas Chancellor's Fund for Innovation, the Arkansas Agricultural Experiment Station, the National Science Foundation (OIA award no. 1430427 to FG), the USDA-NIFA AFRI Foundational Program (grant 2015-67013-23412 to FG), and the Philanthropic Educational Organization (PEO) Scholar Award (to HF).

Arnaiz, A., Rosa-Diaz, I., Romero-Puertas, M. C., Sandalio, L. M., and Diaz, I. (2021). Nitric oxide, an essential intermediate in the plant-herbivore interaction. Front. Plant Sci. 11:2029. doi: 10.3389/fpls.2020.620086

Atamian, H. S., Chaudhary, R., Cin, V. D., Girke, T., and Kaloshian, I. (2013). In planta expression or delivery of potato aphid Macrosiphum euphorbiae effectors Me10 and Me23 enhances aphid fecundity. Mol. Plant Microbe Interact. 26, 67-74. doi: 10.1094/MPMI-06-12-0144-FI

Barna, B., Fodor, J., Harrach, B. D., Pogány, M., and Király, Z. (2012). The Janus face of reactive oxygen species in resistance and susceptibility of plants to necrotrophic and biotrophic pathogens. Plant Physiol. Biochem. 59, 37-43. doi: 10.1016/j.plaphy.2012.01.014 
Bayendi Loudit, S. M., Bauwens, J., and Francis, F. (2018). Cowpea aphid-plant interactions: endosymbionts and related salivary protein patterns. Entomol. Exp. Appl. 166, 460-473. doi: 10.1111/eea.12687

Beffagna, N., and Lutzu, I. (2007). Inhibition of catalase activity as an early response of Arabidopsis thaliana cultured cells to the phytotoxin fusicoccin. J. Exp. Bot. 58, 4183-4194. doi: 10.1093/jxb/erm275

Berner, J. M., and van der Westhuizen, A. J. (2010). Inhibition of xanthine oxidase activity results in the inhibition of Russian wheat aphid-induced defense enzymes. J. Chem. Ecol. 36, 1375-1380. doi: 10.1007/s10886-0109879-y

Bittner, N., Trauer-Kizilelma, U., and Hilker, M. (2017). Early plant defence against insect attack: involvement of reactive oxygen species in plant responses to insect egg deposition. Planta 245, 993-1007. doi: 10.1007/s00425-0172654-3

Blackman, R. L., and Eastop, V. F. (2000). Aphids On the World's Crops: An Identification and Information Guide. Hoboken, NJ: John Wiley \& Sons.

Blackman, R. L., and Eastop, V. F. (2006). Aphids on the World's Herbaceous Plants and Shrubs. New York, NY: John Wiley \& Sons, Inc.

Boissot, N., Schoeny, A., and Vanlerberghe-Masutti, F. (2016). Vat an amazing gene conferring resistance to aphids and viruses they carry: from molecular structure to field effects. Front. Plant Sci. 7:1420. doi: 10.3389/fpls.2016. 01420

Borowiak-Sobkowiak, B., Woźniak, A., Bednarski, W., Formela, M., Samardakiewicz, S., and Morkunas, I. (2016). Brachycorynella asparagi (Mordv.) induced-oxidative stress and antioxidative defenses of Asparagus officinalis L. Int. J. Mol. Sci. 17:1740. doi: 10.3390/ijms1710 1740

Bos, J. I. B., Prince, D., Pitino, M., Maffei, M. E., Win, J., and Hogenhout, S. A. (2010). A functional genomics approach identifies candidate effectors from the aphid species Myzus persicae (green peach aphid). PLoS Genet. 6:e1001216. doi: 10.1371/journal.pgen.1001216

Botha, A.-M., van Eck, L., Burger, N. F. V., and Swanevelder, Z. H. (2014). Nearisogenic lines of Triticum aestivum with distinct modes of resistance exhibit dissimilar transcriptional regulation during Diuraphis noxia feeding. Biol. Open 3, 1116-1126. doi: 10.1242/bio.201410280

Bright, J., Desikan, R., Hancock, J. T., Weir, I. S., and Neill, S. J. (2006). ABAinduced NO generation and stomatal closure in Arabidopsis are dependent on $\mathrm{H}_{2} \mathrm{O}_{2}$ synthesis. Plant J. 45, 113-122. doi: 10.1111/j.1365-313X.2005.02 615.x

Burd, J. D., and Burton, R. L. (1992). Characterization of plant damage caused by Russian wheat aphid (Homoptera: Aphididae). J. Econ. Entomol. 85, 2017-2022. doi: 10.1093/jee/85.5.2017

Carmody, M., Waszczak, C., Idänheimo, N., Saarinen, T., and Kangasjärvi, J. (2016). ROS signalling in a destabilised world: A molecular understanding of climate change. J. Plant Physiol. 203, 69-83. doi: 10.1016/j.jplph.2016.06.008

Carolan, J. C., Caragea, D., Reardon, K. T., Mutti, N. S., Dittmer, N., Pappan, K., et al. (2011). Predicted effector molecules in the salivary secretome of the pea aphid (Acyrthosiphon pisum): a dual transcriptomic/proteomic approach. J. Proteome Res. 10, 1505-1518. doi: 10.1021/pr100881q

Carolan, J. C., Fitzroy, C. I. J., Ashton, P. D., Douglas, A. E., and Wilkinson, T. L. (2009). The secreted salivary proteome of the pea aphid Acyrthosiphon pisum characterised by mass spectrometry. Proteomics 9, 2457-2467. doi: 10.1002/ pmic. 200800692

Chaudhary, R., Atamian, H. S., Shen, Z., Briggs, S. P., and Kaloshian, I. (2014). GroEL from the endosymbiont Buchnera aphidicola betrays the aphid by triggering plant defense. Proc. Natl. Acad. Sci. U.S.A. 111, 8919-8924. doi: $10.1073 /$ pnas.1407687111

Chen, X., Zhang, Z., Vosman, B., and Broekgaarden, C. (2014). Constitutive overexpression of the pollen specific gene SKS13 in leaves reduces aphid performance on Arabidopsis thaliana. BMC Plant Biol. 14:17. doi: 10.1186/ s12870-014-0217-3

Clements, K. M., Sorenson, C. E., Wiegmann, B. M., Neese, P. A., and Roe, R. M. (2000). Genetic, biochemical, and behavioral uniformity among populations of Myzus nicotianae and Myzus persicae. Entomol. Exp. Appl. 95, 269-281. doi: 10.1046/j.1570-7458.2000.00666.x

Czarnocka, W., and Karpiński, S. (2018). Friend or foe? Reactive oxygen species production, scavenging and signaling in plant response to environmental stresses. Free Radic. Biol. Med. 122, 4-20. doi: 10.1016/j.freeradbiomed.2018. 01.011

Czerniewicz, P., Sytykiewicz, H., Durak, R., Borowiak-Sobkowiak, B., and Chrzanowski, G. (2017). Role of phenolic compounds during antioxidative responses of winter triticale to aphid and beetle attack. Plant Physiol. Biochem. 118, 529-540. doi: 10.1016/j.plaphy.2017.07.024

Das, K., and Roychoudhury, A. (2014). Reactive oxygen species (ROS) and response of antioxidants as ROS-scavengers during environmental stress in plants. Front. Environ. Sci. 2:53. doi: 10.3389/fenvs.2014.00053

Delledonne, M., Zeier, J., Marocco, A., and Lamb, C. (2001). Signal interactions between nitric oxide and reactive oxygen intermediates in the plant hypersensitive disease resistance response. Proc. Natl. Acad. Sci. U.S.A. 98, 13454-13459. doi: 10.1073/pnas.231178298

Demidchik, V. (2015). Mechanisms of oxidative stress in plants: from classical chemistry to cell biology. Environ. Exp. Bot. 109, 212-228. doi: 10.1016/j. envexpbot.2014.06.021

Drurey, C., Mathers, C. T., Prince, D. C., Wilson, C., Caceres-Moreno, C., Mugford, S. T., et al. (2019). Chemosensory proteins in the CSP4 clade evolved as plant immunity suppressors before two suborders of plant-feeding hemipteran insects diverged. BioRxiv doi: 10.1101/173278

Durak, R., Bednarski, W., Formela-Luboiñska, M., Woźniak, A., BorowiakSobkowiak, B., Durak, T., et al. (2019). Defense responses of Thuja orientalis to infestation of anholocyclic species aphid Cinara tujafilina. J. Plant Physiol. 232, 160-170. doi: 10.1016/j.jplph.2018.11.018

Elzinga, D. A., De Vos, M., and Jander, G. (2014). Suppression of plant defenses by a Myzus persicae (green peach aphid) salivary effector protein. Mol. Plant Microbe Interact. 27, 747-756. doi: 10.1094/MPMI-01-14-0018- R

Farnese, F. S., Menezes-Silva, P. E., Gusman, G. S., and Oliveira, J. A. (2016). When bad guys become good ones: the key role of reactive oxygen species and nitric oxide in the plant responses to abiotic stress. Front. Plant Sci. 7:471. doi: $10.3389 /$ fpls.2016.00471

Fischer, H. F. (2021). The Influence of Singlet Oxygen and Loss of Function of Fatty Acid Desaturase 7 in the Chloroplast on Aphid Resistance in Arabidopsis thaliana. [dissertation]. Fayetteville, AR: University of Arkansas.

Flors, C., and Nonell, S. (2006). Light and singlet oxygen in plant defense against pathogens: phototoxic phenalenone phytoalexins. Acc. Chem. Res. 39, 293-300. doi: 10.1021/ar0402863

Foley, R. C., Gleason, C. A., Anderson, J. P., Hamann, T., and Singh, K. B. (2013). Genetic and genomic analysis of Rhizoctonia solani interactions with Arabidopsis; evidence of resistance mediated through NADPH oxidases. PLoS One 8:e56814. doi: 10.1371/journal.pone.0056814

Foyer, C. H., and Noctor, G. (2016). Stress-triggered redox signalling: what's in pROSpect? Plant Cell Environ. 39, 951-964. doi: 10.1111/pce.12621

Foyer, C. H., Rasool, B., Davey, J. W., and Hancock, R. D. (2016). Cross-tolerance to biotic and abiotic stresses in plants: a focus on resistance to aphid infestation. J. Exp. Bot. 67, 2025-2037. doi: 10.1093/jxb/erw079

Gadjev, I., Vanderauwera, S., Gechev, T. S., Laloi, C., Minkov, I. N., Shulaev, V., et al. (2006). Transcriptomic footprints disclose specificity of reactive oxygen species signaling in Arabidopsis. Plant Physiol. 141, 436-445. doi: 10.1104/pp. 106.078717

Glazebrook, J. (2005). Contrasting mechanisms of defense against biotrophic and necrotrophic pathogens. Annu. Rev. Phytopathol. 43, 205-227. doi: 10.1146/ annurev.phyto.43.040204.135923

Goggin, F. L., Quisenberry, S. S., and Ni, X. (2017). "Feeding Injury," in Aphids as Crop Pests, 2nd Edn, eds H. M. van Emden and R. Harrington (Oxfordshire: CABI), 303-322.

Goggin, F. L., Williamson, V. M., and Ullman, D. E. (2001). Variability in the response of Macrosiphum euphorbiae and Myzus persicae (Hemiptera: Aphididae) to the tomato resistance gene Mi. Environ. Entomol. 30, 101-106. doi: 10.1603/0046-225X-30.1.101

Guo, H., Gu, L., Liu, F., Chen, F., Ge, F., and Sun, Y. (2019). Aphidborne viral spread is enhanced by virus-induced accumulation of plant reactive oxygen species. Plant Physiol. 179, 143-155. doi: 10.1104/pp.18. 00437

Guo, H., Zhang, Y., Tong, J., Ge, P., Wang, Q., Zhao, Z., et al. (2020). An aphidsecreted salivary protease activates plant defense in phloem. Curr. Biol. 30, 4826.e-4836.e. doi: 10.1016/j.cub.2020.09.020 
Hemetsberger, C., Herrberger, C., Zechmann, B., Hillmer, M., and Doehlemann, G. (2012). The Ustilago maydis effector Pep1 suppresses plant immunity by inhibition of host peroxidase activity. PLoS Pathog. 8:e1002684. doi: 10.1371/ journal.ppat.1002684

Hogenhout, S. A., and Bos, J. I. (2011). Effector proteins that modulate plant-insect interactions. Curr. Opin. Plant Biol. 14, 422-428. doi: 10.1016/j.pbi.2011.05.003

Hou, S., Liu, Z., Shen, H., and Wu, D. (2019). Damage-associated molecular pattern-triggered immunity in plants. Front. Plant Sci. 10:646. doi: 10.3389/fpls. 2019.00646

Jaouannet, M., Morris, J. A., Hedley, P. E., and Bos, J. I. B. (2015). Characterization of Arabidopsis transcriptional responses to different aphid species reveals genes that contribute to host susceptibility and non-host resistance. PLoS Pathog. 11:e1004918. doi: 10.1371/journal.ppat.1004918

Jiang, Y., and Miles, P. W. (1993). Responses of a compatible lucerne variety to attack by spotted alfalfa aphid: changes in the redox balance in affected tissues. Entomol. Exp. Appl. 67, 263-274. doi: 10.1111/j.1570-7458.1993.tb01677.x

Jwa, N.-S., and Hwang, B. K. (2017). Convergent evolution of pathogen effectors toward reactive oxygen species signaling networks in plants. Front. Plant Sci. 8:1687. doi: $10.3389 /$ fpls.2017.01687

Kaloshian, I., and Walling, L. L. (2005). Hemipterans as plant pathogens. Annu. Rev. Phytopathol. 43, 491-521. doi: 10.1146/annurev.phyto.43.040204.135944

Kerchev, P. I., Fenton, B., Foyer, C. H., and Hancock, R. D. (2012). Infestation of potato (Solanum tuberosum L.) by the peach-potato aphid (Myzus persicae Sulzer) alters cellular redox status and is influenced by ascorbate. Plant Cell Environ. 35, 430-440. doi: 10.1111/j.1365-3040.2011.02395.x

Kmieć, K., and Kot, I. (2021). Physiological response of Populus nigra 'Italica' to galling aphids feeding. Plant Biol. 23, 675-679. doi: 10.1111/plb.13265

Kmieć, K., Rubinowska, K., and Golan, K. (2018). Tetraneura ulmi (Hemiptera: Eriosomatinae) induces oxidative stress and alters antioxidant enzyme activities in elm leaves. Environ. Entomol. 47, 840-847. doi: 10.1093/ee/nvy055

Kot, I., and Kmieć, K. (2020). Poplar tree response to feeding by the petiole gall aphid Pemphigus spyrothecae Pass. Insects 11:282. doi: 10.3390/insects11050282

Kuśnierczyk, A., Winge, P., Jørstad, T. S., Troczyñska, J., Rossiter, J. T., and Bones, A. M. (2008). Towards global understanding of plant defence against aphids timing and dynamics of early Arabidopsis defence responses to cabbage aphid (Brevicoryne brassicae) attack. Plant Cell Environ. 31, 1097-1115. doi: 10.1111/ j.1365-3040.2008.01823.x

Kuźniak, E., and Kopczewski, T. (2020). The chloroplast reactive oxygen speciesredox system in plant immunity and disease. Front. Plant Sci. 11:572686. doi: $10.3389 /$ fpls.2020.572686

Lamb, C., and Dixon, R. A. (1997). The oxidative burst in plant disease resistance. Annu. Rev. Plant. Physiol. Plant. Mol. Biol. 48, 251-275. doi: 10.1146/annurev. arplant.48.1.251

Lehmann, S., Serrano, M., L'Haridon, F., Tjamos, S. E., and Metraux, J.-P. (2015). Reactive oxygen species and plant resistance to fungal pathogens. Phytochemistry 112, 54-62. doi: 10.1016/j.phytochem.2014. 08.027

Lei, J., Finlayson, S. A., Salzman, R. A., Shan, L., and Zhu-Salzman, K. (2014). BOTRYTIS-INDUCED KINASE1 modulates Arabidopsis resistance to green peach aphids via PHYTOALEXIN DEFICIENT4. Plant Physiol. 165, 16571670. doi: 10.1104/pp.114.242206

Li, X., Zhang, H., Tian, L., Huang, L., Liu, S., Li, D., et al. (2015). Tomato SlRbohB, a member of the NADPH oxidase family, is required for disease resistance against Botrytis cinerea and tolerance to drought stress. Front. Plant Sci. 6:463. doi: $10.3389 /$ fpls. 2015.00463

Liu, X., Williams, C. E., Nemacheck, J. A., Wang, H., Subramanyam, S., Zheng, C., et al. (2010). Reactive oxygen species are involved in plant defense against a gall midge. Plant Physiol. 152, 985-999. doi: 10.1104/pp.109.150656

Łukasik, I., and Goławska, S. (2019). Biochemical markers of oxidative stress in triticale seedlings exposed to cereal aphids. Acta Biol. Crac. Ser. Bot. 61, 35-46. doi: 10.24425/ABCSB.2019.127745

Łukasik, I., Kornacka, A., Goławska, S., Sytykiewicz, H., Sprawka, I., and Wójcicka, A. (2017). Effects of Acyrtosiphon pisum (Harris) infestation on the hydrogen peroxide content and activity of antioxidant enzymes in Fabaceae plants. Allelopathy J. 40, 143-150. doi: 10.26651/2017-40-1-1073

Łukaszewicz, S., Politycka, B., and Borowiak-Sobkowiak, B. (2021). Effect of selenium on alleviating oxidative stress in pea leaves caused by pea aphid feeding. J. Plant Protect. Res. 61, 83-94.
MacWilliams, J. R., Chesnais, Q., Nabity, P., Mauck, K., and Kaloshian, I. (2021). Cowpea aphid resistance in cowpea line CB77 functions primarily through antibiosis and eliminates phytotoxic symptoms of aphid feeding. Res. Sq. 2021:522914. doi: 10.21203/rs.3.rs-522914/v1

Madhusudhan, V. V., and Miles, P. W. (1998). Mobility of salivary components as a possible reason for differences in the responses of alfalfa to the spotted alfalfa aphid and pea aphid. Entomol. Exp. Appl. 86, 25-39. doi: 10.1046/j.1570-7458. 1998.00262.x

Mai, V. C., Bednarski, W., Borowiak-Sobkowiak, B., Wilkaniec, B., Samardakiewicz, S., and Morkunas, I. (2013). Oxidative stress in pea seedling leaves in response to Acyrthosiphon pisum infestation. Phytochem. 93, 49-62. doi: 10.1016/j.phytochem.2013.02.011

Mai, V. C., Drzewiecka, K., Jeleñ, H., Narożna, D., Ruciñska-Sobkowiak, R., Kêsy, J., et al. (2014). Differential induction of Pisum sativum defense signaling molecules in response to pea aphid infestation. Plant Sci. 221-222, 1-12. doi: 10.1016/j.plantsci.2014.01.011

Mai, V.-C., Nguyen, B.-H., Nguyen, D.-D., and Nguyen, L.-A.-V. (2017). Nostoc calcicola extract improved the antioxidative response of soybean to cowpea aphid. Bot. Stud. 58:55. doi: 10.1186/s40529-017-0211-9

Mai, V. C., Tran, N. T., and Nguyen, D. S. (2016). The involvement of peroxidases in soybean seedlings' defense against infestation of cowpea aphid. Arthropod Plant Interact. 10, 283-292. doi: 10.1007/s11829-016-9424-1

Martinez, de Ilarduya, O. M., Xie, Q., and Kaloshian, I. (2003). Aphid-induced defense responses in $\mathrm{Mi}$-1-mediated compatible and incompatible tomato interactions. Mol. Plant Microbe Interact. 16, 699-708. doi: 10.1094/MPMI. 2003.16.8.699

Miles, P. W. (1978). Redox reactions of Hemipterous saliva in plant issues. Entomol. Exp. Appl. 24, 534-539. doi: 10.1111/j.1570-7458.1978.tb02814.x

Miles, P. W. (1989). "Specific responses and damage caused by Aphidoidae," in Aphids, Their Biology, Natural Enemies and Control, (Amsterdam: Elsevier), 23-47.

Miles, P. W. (1999). Aphid saliva. Biol. Rev. Biol. Proc. Camb. Philos. Soc. 74, 41-85. doi: 10.1111/j.1469-185X.1999.tb00181.x

Miller, G., Schlauch, K., Rachel, T., Cortes, D., Torres, M. A., Shulaev, V., et al. (2009). The Plant NADPH oxidase RBOHD mediates rapid systemic signaling in response to diverse stimuli. Sci. Signal. 2, 1-11. doi: 10.1126/scisignal. 2000448

Moloi, M. J., and Van Der Westhuizen, A. J. (2006). The reactive oxygen species are involved in resistance responses of wheat to the Russian wheat aphid. J. Plant Physiol. 163, 1118-1125. doi: 10.1016/j.jplph.2005.07.014

Moloi, M. J., and van der Westhuizen, A. J. (2014). Involvement of nitric oxide in the Russian wheat aphid resistance response of wheat. Cereal Res. Commun. 42, 119-125. doi: 10.1556/CRC.2013.0044

Moloi, M. J., van der Westhuizen, A. J., and Jankielsohn, A. (2014). Nitric oxide is an upstream signal involved in the multisignalling network during the Russian wheat aphid resistance response and its application enhances resistance. Cereal Res. Commun. 43, 29-40. doi: 10.1556/CRC.2014.0018

Nicholson, S. J., and Puterka, G. J. (2014). Variation in the salivary proteomes of differentially virulent greenbug (Schizaphis graminum Rondani) biotypes. J. Proteomics 105, 186-203. doi: 10.1016/j.jprot.2013.12.005

Noctor, G., Reichheld, J.-P., and Foyer, C. H. (2016). ROS-related redox regulation and signaling in plants. Semin. Cell Dev. Biol. 80, 3-12. doi: 10.1016/j.semcdb. 2017.07.013

O'Brien, J. A., Daudi, A., Butt, V. S., and Bolwell, G. P. (2012). Reactive oxygen species and their role in plant defence and cell wall metabolism. Planta 236, 765-779. doi: 10.1007/s00425-012-1696-9

Ortega-Villasante, C., Burén, S., Blázquez-Castro, A., Baron-Sola, A., and Hernandez, L. E. (2018). Fluorescent in vivo imaging of reactive oxygen species and redox potential in plants. Free Radic. Biol. Med. 122, 202-220. doi: 10.1016/ j.freeradbiomed.2018.04.005

Pant, S., and Huang, Y. (2021). Elevated production of reactive oxygen species is related to host plant resistance to sugarcane aphid in sorghum. Plant Signal. Behav. 16, 1849523. doi: 10.1080/15592324.2020.1849523

Peccoud, J., Simon, J.-C., von Dohlen, C., Coeur d'acier, A., Plantegenest, M., et al. (2010). Evolutionary history of aphid-plant associations and their role in aphid diversification. C.R. Biol. 333, 474-487. doi: 10.1016/j.crvi.2010.03.004

Pogány, M., von Rad, U., Grün, S., Dongó, A., Pintye, A., Simoneau, P., et al. (2009). Dual roles of reactive oxygen species and NADPH oxidase RBOHD 
in an Arabidopsis-Alternaria pathosystem. Plant Physiol. 151, 1459-1475. doi: 10.1104/pp.109.141994

Pointeau, S., Ameline, A., Laurans, F., Sallé, A., Rahbé, Y., Bankhead-Dronnet, S., et al. (2012). Exceptional plant penetration and feeding upon cortical parenchyma cells by the woolly poplar aphid. J. Insect Physiol. 58, 857-866. doi: 10.1016/j.jinsphys.2012.03.008

Pollard, D. G. (1973). Plant penetration by feeding aphids (Hemiptera, Aphidoidea): a review. Bull. Entomol. Res. 62, 631-714. doi: 10.1017/ S0007485300005526

Prince, D. C., Drurey, C., Zipfel, C., and Hogenhout, S. A. (2014). The Leucine-Rich Repeat Receptor-Like Kinase BRASSINOSTEROID INSENSITIVE1ASSOCIATED KINASE1 and the Cytochrome P450 PHYTOALEXIN DEFICIENT 3 contribute to innate immunity to aphids in Arabidopsis. Plant Physiol. 164, 2207-2219. doi: 10.1104/pp.114.235598

Queval, G., Hager, J., Gakière, B., and Noctor, G. (2008). Why are literature data for $\mathrm{H}_{2} \mathrm{O}_{2}$ contents so variable? A discussion of potential difficulties in the quantitative assay of leaf extracts. J. Exp. Bot. 59, 135-146. doi: 10.1093/jxb/ erm193

Quisenberry, S. S., and Ni, X. (2007). "Feeding Injury," in Aphids as Crop Pests, eds H. M. van Emden and R. Harrington $1^{\text {st }}$ (Oxfordshire: CABI), 331-352.

Rao, S. A. K., Carolan, J. C., and Wilkinson, T. L. (2013). Proteomic profiling of cereal aphid saliva reveals both ubiquitous and adaptive secreted proteins. PLoS One 8:e57413. doi: 10.1371/journal.pone.0057413

Rashid, M. H. O., Khan, A., Hossain, M. T., and Chung, Y. R. (2017). Induction of systemic resistance against aphids by endophytic Bacillus velezensis YC7010 via expressing PHYTOALEXIN DEFICIENT4 in Arabidopsis. Front. Plant Sci. 8:211. doi: $10.3389 /$ fpls.2017.00211

Rasool, B., Karpinska, B., Pascual, J., Kangasjärvi, S., and Foyer, C. H. (2019). Catalase, glutathione, and protein phosphatase 2A-dependent organellar redox signalling regulate aphid fecundity under moderate and high irradiance. Plant Cell Environ. 43, 209-222. doi: 10.1111/pce.13669

Rasool, B., McGowan, J., Pastok, D., Marcus, S. E., Morris, J. A., Verrall, S. R., et al. (2017). Redox control of aphid resistance through altered cell wall composition and nutritional quality. Plant Physiol. 175, 259-271. doi: 10.1104/pp.17. 00625

Ren, G., Wang, X., Chen, D., Wang, X., and Liu, X. (2014). Effects of aphids Myzus persicae on the changes of $\mathrm{Ca}^{2+}$ and $\mathrm{H}_{2} \mathrm{O}_{2}$ flux and enzyme activities in tobacco. J. Plant Inter. 9, 883-888. doi: 10.1080/17429145.2014.982221

Rossi, F. R., Krapp, A. R., Bisaro, F., Maiale, S. J., and Carrillo, N. (2017). Reactive oxygen species generated in chloroplasts contribute to tobacco leaf infection by the necrotrophic fungus Botrytis cinerea. Plant J. 92, 761-773. doi: 10.1111/tpj. 13718

Rossi, M., Goggin, F. L., Milligan, S. B., Kaloshian, I., Ullman, D. E., and Williamson, V. M. (1998). The nematode resistance gene Mi of tomato confers resistance against the potato aphid. Proc. Natl. Acad. Sci. U S A 95, 9750-9754. doi: $10.1073 /$ pnas. 95.17 .9750

Ryan, J. D., Morgham, A. T., Richardson, P. E., Johnson, R. C., Mort, A. J., and Eikenbary, R. D. (1990). "Greenbugs and wheat: a model system for the study of phytotoxic Homoptera," in Aphid-Plant Genotype Interactions, eds R. K. Campbell and R. D. Eikenbary (Amsterdam: Elsevier), $171-186$.

Saheed, S. A., Liu, L., Jonsson, L., and Botha, C. E. J. (2007). Xylem - as well as phloem - sustains severe damage due to feeding by the Russian wheat aphid. $S$. Afr. J. Bot. 73, 593-599. doi: 10.1016/j.sajb.2007.05.008

Segmüller, N., Kokkelink, L., Giesbert, S., Odinius, D., van Kan, J., and Tudzynski, P. (2008). NADPH Oxidases are involved in differentiation and pathogenicity in Botrytis cinerea. Mol. Plant Microbe Interact. 21, 808-819. doi: 10.1094/MPMI21-6-0808

Sewelam, N., Jaspert, N., Van Der Kelen, K., Tognetti, V. B., Schmitz, J., Frerigmann, H., et al. (2014). Spatial $\mathrm{H}_{2} \mathrm{O}_{2}$ signaling specificity: $\mathrm{H}_{2} \mathrm{O}_{2}$ from chloroplasts and peroxisomes modulates the plant transcriptome differentially. Mol. Plant 7, 1191-1210. doi: 10.1093/mp/ssu070

Shao, Y., Guo, M., He, X., Fan, Q., Wang, Z., Jia, J., et al. (2019). Constitutive $\mathrm{H}_{2} \mathrm{O}_{2}$ is involved in sorghum defense against aphids. Braz. J. Bot. 42, 271-281. doi: 10.1007/s40415-019-00525-2

Shapiguzov, A., Vainonen, J., Wrzaczek, M., and Kangasjärvi, J. (2012). ROS-talk how the apoplast, the chloroplast, and the nucleus get the message through. Front. Plant Sci. 3:292. doi: 10.3389/fpls.2012.00292
Sharma, P., Jha, A. B., Dubey, R. S., and Pessarakli, M. (2012). Reactive oxygen species, oxidative damage, and antioxidative defense mechanism in plants under stressful conditions. J. Bot. 2012, e217037. doi: 10.1155/2012/217037

Shoala, T., Edwards, M. G., Knight, M. R., and Gatehouse, A. M. R. (2018). OXI1 kinase plays a key role in resistance of Arabidopsis towards aphids (Myzus persicae). Transgenic Res. 27, 355-366. doi: 10.1007/s11248-018-0078-x

Singh, B. U., Padmaja, P. G., and Seetharama, N. (2004). Biology and management of the sugarcane aphid, Melanaphis sacchari (Zehntner) (Homoptera: Aphididae), in sorghum: a review. Crop Protect. 23, 739-755. doi: 10.1016/j. cropro.2004.01.004

Stevens, M., and Lacomme, C. (2017). "Transmission of Plant Viruses," in Aphids as Crop Pests, 2nd Edn, eds H. M. van Emden and R. Harrington (Oxfordshire: CABI), 323-347.

Sun, M., Voorrips, R. E., and Vosman, B. (2020). Aphid populations showing differential levels of virulence on Capsicum accessions. Insect Sci. 27, 336-348. doi: 10.1111/1744-7917.12648

Sun, Y., Xia, X. L., Jiang, J. F., Chen, S. M., Chen, F. D., and Lv, G. S. (2016). Salicylic acid-induced changes in physiological parameters and genes of the flavonoid biosynthesis pathway in Artemisia vulgaris and Dendranthema nankingense during aphid feeding. Gen. Mol. Res. 15:1. doi: 10.4238/gmr.15017546

Sytykiewicz, H. (2015). Transcriptional responses of catalase genes in maize seedlings exposed to cereal aphids' herbivory. Biochem. Syst. Ecol. 60, 131-142. doi: 10.1016/j.bse.2015.04.015

Sytykiewicz, H. (2016). Deciphering the role of NADPH oxidase in complex interactions between maize (Zea mays L.) genotypes and cereal aphids. Biochem. Biophys. Res. Commun. 476, 90-95. doi: 10.1016/j.bbrc.2016.0 5.050

Sytykiewicz, H., Chrzanowski, G., Czerniewicz, P., Sprawka, I., Łukasik, I., et al. (2014). Expression profiling of selected glutathione transferase genes in Zea mays (L.) seedlings infested with cereal aphids. PLoS One 9:e111863. doi: 10. 1371/journal.pone.0111863

Thatcher, L. F., Foley, R., Casarotto, H. J., Gao, L.-L., Kamphuis, L. G., Melser, S., et al. (2018). The Arabidopsis RNA Polymerase II Carboxyl Terminal Domain (CTD) Phosphatase-Like1 (CPL1) is a biotic stress susceptibility gene. Sci. Rep. 8, 1-14. doi: 10.1038/s41598-018-31837-0

Tjallingii, W. F., and Esch, T. H. (1993). Fine structure of aphid stylet routes in plant tissues in correlation with EPG signals. Physiol. Entomol. 18, 317-328. doi: 10.1111/j.1365-3032.1993.tb00604.x

Veselova, S. V., Burkhanova, G. F., Rumyantsev, S. D., Blagova, D. K., and Maksimov, I. V. (2019). Strains of Bacillus spp. regulate wheat resistance to Greenbug Aphid Schizaphis graminum Rond. Appl. Biochem. Microbiol. 55, 41-47. doi: 10.1134/S0003683819010186

Wada, S., Cui, S., and Yoshida, S. (2019). Reactive Oxygen Species (ROS) generation is indispensable for haustorium formation of the root parasitic plant Striga hermonthica. Front. Plant Sci. 10:328. doi: 10.3389/fpls.2019.00328

Wang, Q., Yuan, E., Ling, X., Zhu-Salzman, K., Guo, H., Ge, F., et al. (2020). An aphid facultative symbiont suppresses plant defence by manipulating aphid gene expression in salivary glands. Plant Cell Environ. 43, 2311-2322. doi: $10.1111 /$ pce. 13836

Wang, W., Chen, D., Zhang, X., Liu, D., Cheng, Y., and Shen, F. (2018). Role of plant respiratory burst oxidase homologs in stress responses. Free Radic. Res. 52, 826-839. doi: 10.1080/10715762.2018.1473572

Wang, Y., Loake, G., and Chu, C. (2013). Cross-talk of nitric oxide and reactive oxygen species in plant programed cell death. Front. Plant Sci. 4:314. doi: 10.3389/fpls.2013.00314

Waszczak, C., Carmody, M., and Kangasjärvi, J. (2018). Reactive oxygen species in plant signaling. Annu. Rev. Plant. Biol. 69, 209-236. doi: 10.1146/annurevarplant-042817-040322

Woźniak, A., Bednarski, W., Dancewicz, K., Gabryś, B., Borowiak-Sobkowiak, B., Bocianowski, J., et al. (2019). Oxidative stress links response to lead and Acyrthosiphon pisum in Pisum sativum L. J. Plant Physiol. 240:152996. doi: 10.1016/j.jplph.2019.152996

Woźniak, A., Formela, M., Bilman, P., Grześkiewicz, K., Bednarski, W., Marczak, Ł, et al. (2017). The dynamics of the defense strategy of pea induced by exogenous nitric oxide in response to aphid infestation. Int. J. Mol. Sci. 18:E329. doi: $10.3390 / \mathrm{ijms} 18020329$

Xu, J., Padilla, C. S., Li, J., Wickramanayake, J., Fischer, H. D., and Goggin, F. L. (2021). Redox responses of Arabidopsis thaliana to the green peach 
aphid, Myzus persicae. Mol. Plant Pathol. 2021:13054. doi: 10.1111/mpp. 13054

Yang, H., Mu, J., Chen, L., Feng, J., Hu, J., Li, L., et al. (2015). S-nitrosylation positively regulates ascorbate peroxidase activity during plant stress responses. Plant Physiol. 167, 1604-1615. doi: 10.1104/pp.114.255216

Yao, L., Yang, B., Ma, X., Wang, S., Guan, Z., Wang, B., et al. (2020). A genome-wide view of transcriptional responses during Aphis glycines infestation in soybean. Int. J. Mol. Sci. 21:5191. doi: 10.3390/ijms21155191

Zhang, Y., Fu, Y., Fan, J., Li, Q., Francis, F., and Chen, J. (2019). Comparative transcriptome and histological analyses of wheat in response to phytotoxic aphid Schizaphis graminum and non-phytotoxic aphid Sitobion avenae feeding. BMC Plant Biol. 19:547. doi: 10.1186/s12870-019-2148-5

Zhang, Z., Henderson, C., and Gurr, S. J. (2004). Blumeria graminis secretes an extracellular catalase during infection of barley: potential role in suppression of host defence. Mol. Plant Pathol. 5, 537-547. doi: 10.1111/j.1364-3703.2004. 00251.x
Conflict of Interest: The authors declare that the research was conducted in the absence of any commercial or financial relationships that could be construed as a potential conflict of interest.

Publisher's Note: All claims expressed in this article are solely those of the authors and do not necessarily represent those of their affiliated organizations, or those of the publisher, the editors and the reviewers. Any product that may be evaluated in this article, or claim that may be made by its manufacturer, is not guaranteed or endorsed by the publisher.

Copyright $\odot 2022$ Goggin and Fischer. This is an open-access article distributed under the terms of the Creative Commons Attribution License (CC BY). The use, distribution or reproduction in other forums is permitted, provided the original author(s) and the copyright owner(s) are credited and that the original publication in this journal is cited, in accordance with accepted academic practice. No use, distribution or reproduction is permitted which does not comply with these terms. 